\title{
3D Printed Stackable Titer Plate Inserts Supporting Three Interconnected Tissue Models for Drug Transport Studies
}

Jepsen, Morten Leth; Willumsen, Andreas; Mazzoni, Chiara; Boisen, Anja; Nielsen, Line Hagner; Dufva, Martin

Published in:

Advanced Biosystems

Link to article, DOI:

10.1002/adbi.201900289

Publication date:

2020

Document Version

Peer reviewed version

Link back to DTU Orbit

Citation (APA):

Jepsen, M. L., Willumsen, A., Mazzoni, C., Boisen, A., Nielsen, L. H., \& Dufva, M. (2020). 3D Printed Stackable Titer Plate Inserts Supporting Three Interconnected Tissue Models for Drug Transport Studies. Advanced Biosystems, 4(7), [1900289]. https://doi.org/10.1002/adbi.201900289

\section{General rights}

Copyright and moral rights for the publications made accessible in the public portal are retained by the authors and/or other copyright owners and it is a condition of accessing publications that users recognise and abide by the legal requirements associated with these rights.

- Users may download and print one copy of any publication from the public portal for the purpose of private study or research.

- You may not further distribute the material or use it for any profit-making activity or commercial gain

- You may freely distribute the URL identifying the publication in the public portal 
DOI: $10.1002 /(($ please add manuscript number))

Article type: Full Paper

3D-Printed Stackable Titer Plate Inserts Supporting Three Interconnected Tissue Models for Drug transport studies.

Morten Leth Jepsen, Andreas Willumsen, Chiara Mazzoni, Anja Boisen, Line Hagner Nielsen and Martin Dufva*

MSc M. L. J., BSc A. W., Dr. C. M., Prof. A. B., Dr. L. H. N., Dr. M. D.,

The Danish National Research Foundation and Villum Foundation's Center for Intelligent Drug Delivery and Sensing Using Microcontainers and Nanomechanics (IDUN), Department of Health Technology, Technical University of Denmark, Ørsteds Plads 345C, 2800 Kgs. Lyngby, Denmark.

*Corresponding author: E-mail: dufva@dtu.dk

Keywords: tissue engineering, Caco-2 cells, HUVEC cells, HepG2 cells, first pass metabolism 
Current in vitro drug screening methods often rely on single cell-models and are therefore imprecise in predicting drug absorption, distribution, metabolism, excretion, and toxicity. This study presents a method to fabricate 3D printed inserts that are compatible with commercially available titer plates. Hydrogels can be casted into the inserts and cells can be cultured either in or on the hydrogels. Once individual cell cultures are fully differentiated, the three different cell cultures are stacked on top of each other for biological experiments. To show the possibilities of this approach, three tissue models representing the first pass metabolism was used. The three tissue models are based on gelatin hydrogels and Caco-2, HUVEC, and HepG2 cells to simulate the small intestine, vascular endothelium, and liver, respectively. The device is simple to fabricate, user friendly and is, an alternative to microfluidic-based organ on a chip system. The presented first pass metabolism study allows for gaining information on drug absorption, distribution, metabolism, and, in the future, excretion in one compact device complying the micro titer plate format. 


\section{Introduction}

Oral drug administration is preferred due to low cost and high patient compliance. ${ }^{[1]} 60 \%$ of all drugs are administered orally emphasizing the importance of this administration route. ${ }^{[2]}$ Drug development usually takes $10-15$ years and costs up to $\$ 1.8$ billion in total, ${ }^{[3,4]}$ and improving the research and the development phases will have the biggest cost reducing effect. ${ }^{[4]}$ Nearly, $90 \%$ of drugs identified as lead candidates using current in vitro methods, such as immortalized cell lines and purified tissue sections, fail to reach the market. Furthermore, $50 \%$ of the drug candidates and/or drug formulations fail due to too low oral bioavailability and/or hepatic toxicity issues during phase I clinical trials.$^{[5-7]}$ Pre-clinical in vitro testing of absorption, distribution, metabolism, and excretion (ADME) may reduce the number of failures in phase I clinical trials. Currently, each step of ADME is investigated individually using specialized cell lines. However, multicellular co-cultures have been developed for preclinical drug screening. ${ }^{[8]}$ Typically, oral absorption studies are performed in transwell systems with single cell lines which are designed to model a biological barrier such as the small intestine. ${ }^{[9-12]}$

Microfluidic devices can connect multiple cells types for ADME testing. ${ }^{[13-16]}$ However, microfluidic devices are difficult to up-scale because they have a tendency to be rather complex as they require tubes and pumps. While commercial systems are available, these are also not necessarily trivial to use. ${ }^{[14,15]}$ Previously, a microfluidic system with multiple connected cell layers of colon adenocarcinoma cells (Caco-2), human umbilical vein endothelial cells (HUVEC), and Michigan Cancer Foundation-7 (MCF-7) cells, and hepatocytes on polycarbonate membranes has been presented. ${ }^{[13]}$ However, when aiming for ADME testing of microparticles or drug delivery systems up to $400 \mu \mathrm{m}$ in size, ${ }^{[17-20]}$ there is a need for ADME test systems larger than those supported by microfluidics where channels are normally a few hundred $\mu \mathrm{m}$ in height. ${ }^{[13,14,21]}$ Furthermore, most reported microfluidics systems are made of the polymer polydimethylsiloxane (PDMS). PDMS has many properties suitable for this 3 
application, but small hydrophobic molecules have a tendency to diffuse into PDMS which can be problematic. ${ }^{[22-25]}$

In vivo, tissues are very soft. ${ }^{[26]}$ Culturing of cells in a softer matrix gives a more in vivolike environment for the cell cultures than on hard plastic surfaces, because cells sense the stiffness of their growth matrix. ${ }^{[27]}$ Epithelial cells grown on a soft matrix display organization and polarity which resembled the phenotype found in vivo. ${ }^{[28]}$ To obtain soft growth matrices, hydrogels have been utilized to replace the hard polycarbonate or polyester filters used in microfluidics and transwells. Cells have been cultured both inside and on top of hydrogel growth-matrices. ${ }^{[29-34]}$ Transwell inserts contain a rigid membrane, but it can be functionalized with collagen or other hydrogels to obtain the softer mechanical properties or provide a true 3D environment. ${ }^{[33-35]}$ Caco-2 cells grown on hydrogel growth-matrices have been shown to have higher paracellular permeability than when grown on polyester filters. ${ }^{[33]}$ This is closer to the in vivo situation. Gelatin is denatured collagen and when cross-linked by microbial transglutaminase (mTG), a heat resistant hydrogel can be obtained. ${ }^{[36,37]}$ This has been done with cell cultures such as HepG2 hepatocytes, ${ }^{[31,38]}$ mesenchymal stem cells, ${ }^{[39]}$ and adipose tissue-derived stromal cells. ${ }^{[40]}$

The aim of the presented study was to design and test a set of simple-to-use and easy to fabricate 12 well plate stackable inserts that addresses most of the current limitations of transwells and microfluidics technology for connected in vitro cell models.

\section{Results and Discussion}

\subsection{Triple Layered Tissue Models}

The design of the triple layered tissue models was inspired by commercially available inserts for cell culture titer plates. The three layers were designed so that the tissue layers could be 
cultured independently of each other and easily assembled before use, e.g. for drug transport studies.

\subsubsection{Principle of the Triple Layered Tissue Models}

A completely assembled layered system had in total 36 tissue models (three layers of 12-well titer plates inserts) organized in 12 independent test sites (Figure 1A). Each well of the three inserts had a hole where a hydrogel was casted into, resulting in suspended hydrogel growthmatrices. The suspended hydrogels were utilized as growth matrices for the cell cultures. Cells grew on the apical side of the hydrogel to model a 2D barrier or inside the gel to achieve a 3D spheroid culture. The holes for 3D spheroid tissue models were $5 \mathrm{~mm}$ in diameter and $4 \mathrm{~mm}$ in depth to support a thick hydrogel resembling a solid tissue. The holes for 2D barrier tissuemodels in each well were $5 \mathrm{~mm}$ in diameter and $1 \mathrm{~mm}$ in depth to gain a thinner hydrogel. To support the thin hydrogel, a small cross was lowered $0.5 \mathrm{~mm}$ from the edge of the hole to ensure that the membrane did not bend. This was necessary, since soft and thin gelatin hydrogels have a tendency to bend which can result in cells detachment. ${ }^{[41]}$ Critical for drug-transport studies the inserts were designed to allow for sampling of the medium between each layer (Figure 1C). This way the drug could be followed all the way through the three tissue models without disturbing the cell layers. The was also intended to be used for transepithelial electrical resistance (TEER) measurements.

3D-printed inserts compatible with cell growth were achieved by 3D printing with Dental LT resin on a Form 2 3D printer. To obtain compatibility with cell growth, the 3Dprinted inserts were thoroughly cleaned (Experimental Section). The cleaning protocol differed from the manufacturer's instructions but ensured good biocompatibility at least for the three tested cell lines (Caco-2, HUVEC, and HepG2). It was found that if the 3D printed inserts were not cleaned probably, biocompatibility issues arose, resulting in cell detachment (Figure S1). 
The basic design allowed for cells to be matured and cultured before stacking them together (Figure 1B). Growing each cell line individually would avoid incompatibilities of mediums. ${ }^{[42]}$ Stacking tissue models after maturation (Figure 1B-C) in neutral buffer such as HBSS would minimize impact of different mediums but only sustain shorter tests (hours).

Many organizations of the three insets are possible. Below, we investigate usage of epithelialand endothelial-cells and hepatocytes to mimic the first path metabolism of oral drug delivery. Oher combinations could be endothelial cells, hepatocytes, cancer cells to models drugs injected in the blood stream, metabolized in the hepatocytes and killing cancer cells. ${ }^{[43]}$

A
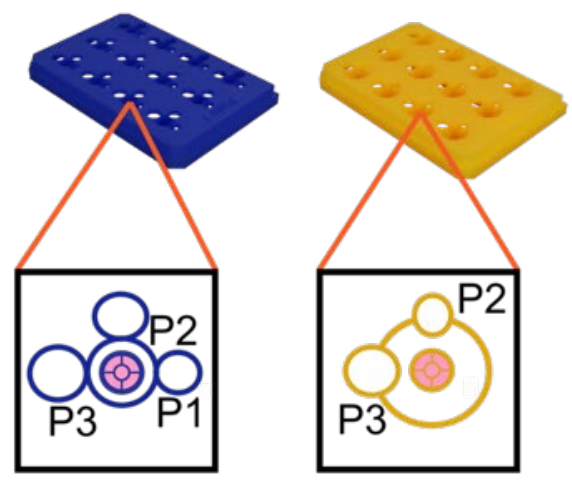

C

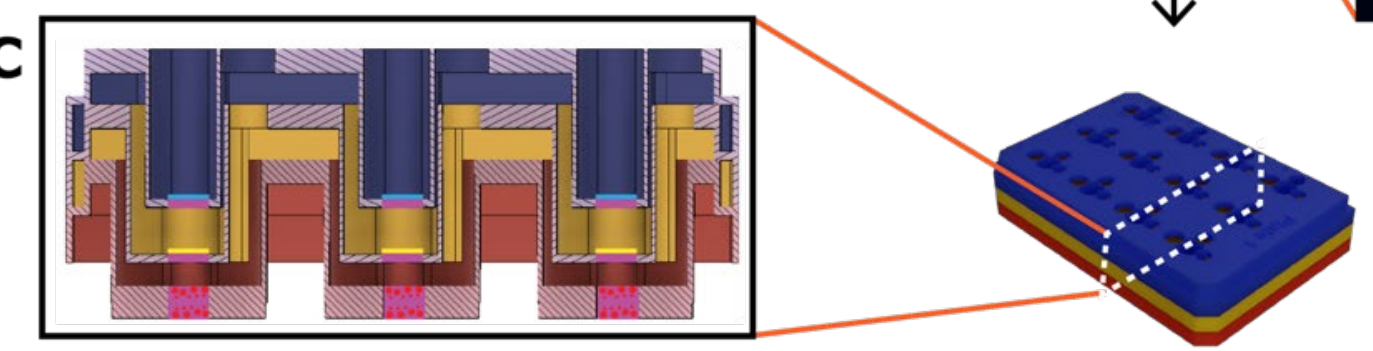

B

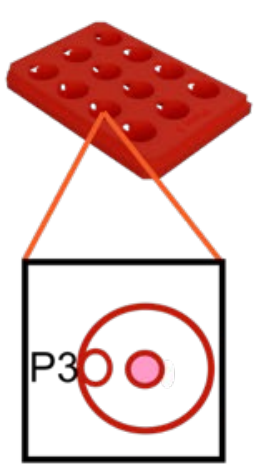

Intestinal layer

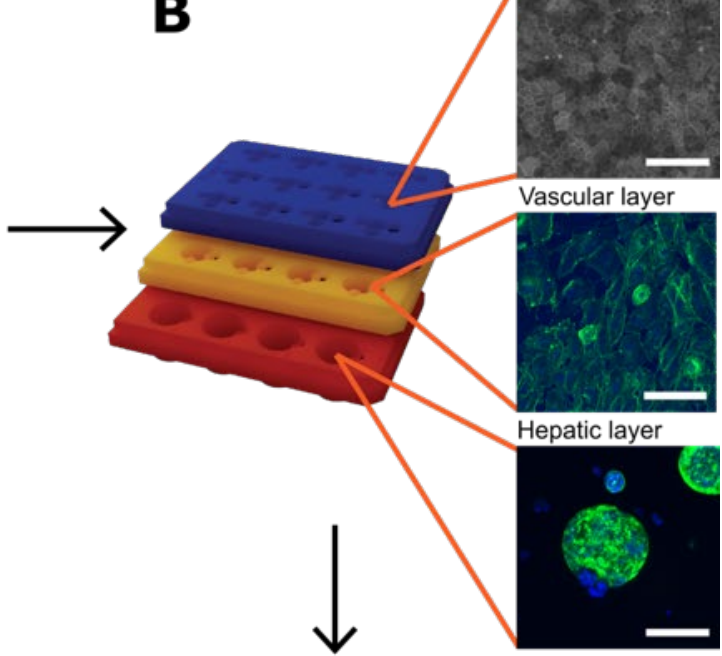

Figure 1: Schematic illustrations of tissue-model inserts. A) Individual tissue-model inserts with Caco-2 cells in blue, HUVEC in yellow, and HepG2 in red. Hydrogels are shown in pink. Sampling holes at each level, P1 for sampling under the blue insert, P2 for sampling under the yellow insert, and P3 for sampling under the red insert. B) Assembly of tissue-model inserts. Scalebar: $100 \mu \mathrm{m}$. C) Sideview of assembled tissue-model inserts. 
Previously, in vitro microfluidics systems combining cellular barriers and underlying tissues have been published. ${ }^{[13,14,44]}$ However, it is difficult to scale microfluidic devices for high throughput screening applications, whereas a system based on titer plates is scalable. A microfluidic system with eight parallel intestinal barrier-models has previously been developed in our laboratory. ${ }^{[45]}$ In contrast, the presented method of three 3D-printed inserts allowed for 12 parallel repetitions with three different tissue models in each. Furthermore, the presented method meets the demand for the possibility of testing microparticles and microfabricated devices for oral drug delivery that are typically $400 \mu \mathrm{m}$ or larger. ${ }^{[17-19]}$ This is not possible with the microfluidic system as these typically have channels in the range of few hundreds $\mu \mathrm{m}$. ${ }^{[13,14,21]}$ Since, the radius of the smallest well of the presented method was $5 \mathrm{~mm}$, microparticles and microfabricated devices can be tested with this method (Figure S2A).

\subsubsection{Casting of Gelatin Hydrogels into the $3 D$ Printed Compartments}

Gelatin hydrogels casted into the 3D-printed inserts were used as growth matrixes for the cells. We have previously functionalized hanging inserts by dipping the inserts into gelatin/mTG solution. ${ }^{[41]}$ However, that resulted in thin and flexible gel which was not desired. Instead, a casting procedure was developed. The holes were closed by 3D-printed pillars covered by parafilm (Figure S3A). To ensure a tight seal from the pillars, they were placed upon springs and the inserts were held down by rubber bands (Figure S3B). Afterwards, hydrogel solution was pipetted into the holes (Figure S3C). After cross-linking and disassembly of the casting device, the inserts were placed in a standard twelve well-plate with medium (Figure S3D).

The gelatin hydrogel did not need coating since cells can secrete their own extracellular matrix to provide structural support. Therefore, the biopolymeric matrix only needed to provide an initial support and set of cues for cell adhesion and growth. ${ }^{[46]}$ 


\subsection{Establishment of an in vitro first pass metabolism model}

To demonstrate the principle of the triple layered transport system, the first pass metabolism was recreated with three different cell lines. The Caco-2 cell line was used to model the small intestinal barrier. This cell line differentiates spontaneously to polarized enterocyte-like cells expressing tight junctions, microvilli, and brush border enzymes. ${ }^{[47]}$ The HUVEC cell line, a primary non-immortalized cell line of human origin, ${ }^{[48,49]}$ was used to model the vascular endothelium. HepG2 cells, the most widely used human hepatoma cell line for studying pharmaco-toxicology, ${ }^{[50]}$ was used to model the liver. These cell lines requires different medium and time in order to develop. Caco-2 developed for three weeks in Dulbecco's modified Eagle's medium (DMEM), HUVECs for two days in endothelial cell growth medium (ECGM), whereas HepG2 cells were grown for three weeks in Roswell Park Memorial Institute (RPMI 1640) medium. 


\section{A}

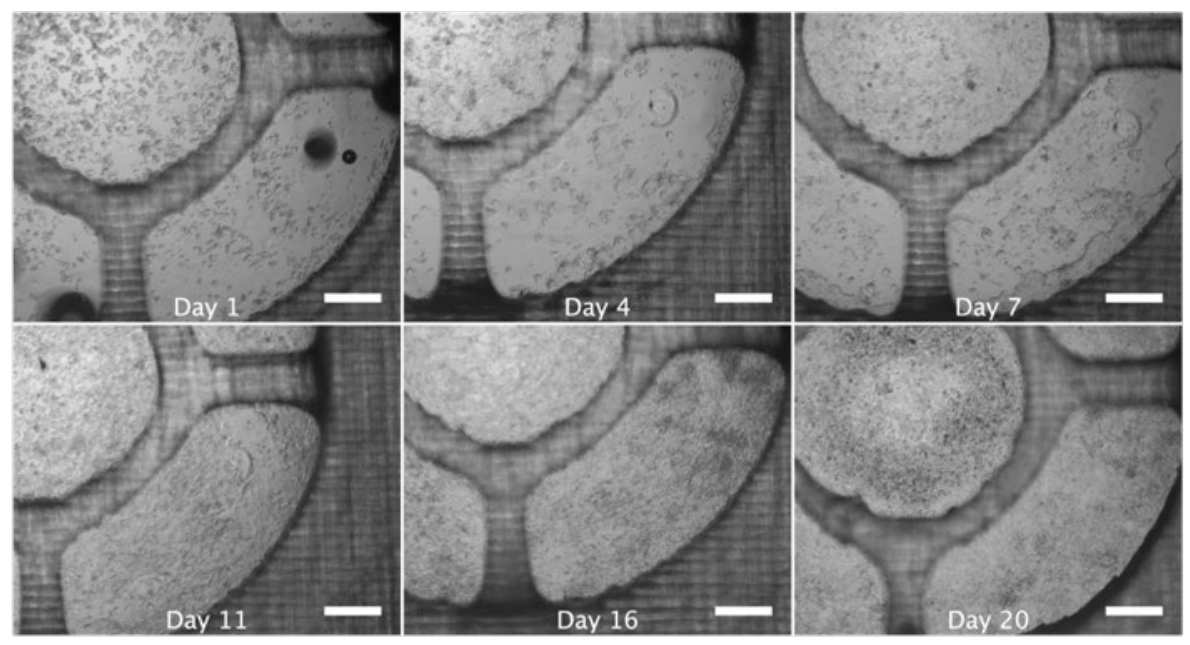

B

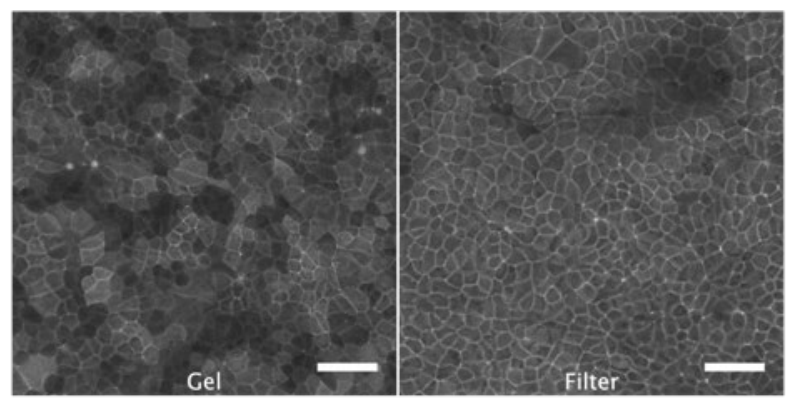

C

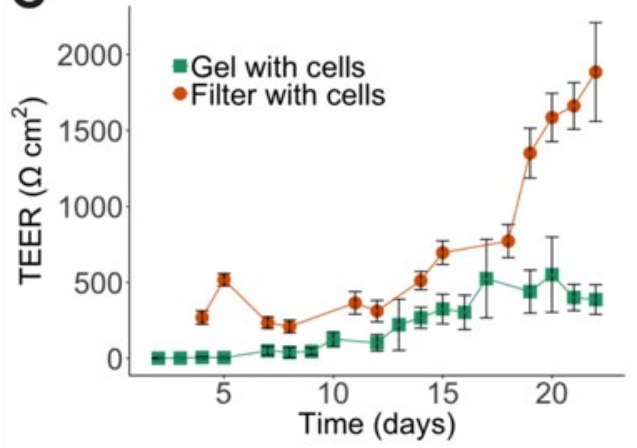

Figure 2: A) Growth of Caco-2 cells on the hydrogel growth-matrix over 20 days. Scalebars: $1000 \mu \mathrm{m}$. B) Tight junction (ZO1) stain of Caco-2 cells on the hydrogel growth-matrix and polyester filters after 20 days. Scalebars: $50 \mu \mathrm{m}$. C) TEER value measurements for Caco-2 cells on the hydrogel growth-matrix (mean $\pm \mathrm{SD}, \mathrm{n}=16)$ and on polyester filter $(\mathrm{mean} \pm \mathrm{SD}, \mathrm{n}=8)$ over three weeks.

\subsubsection{Characterization of the Intestinal Layer of Caco-2 cells}

Caco-2 cells grown on the hydrogel growth-matrices became a tight and evenly distributed monolayer after three weeks of growth (Figure 2A, S4). Caco-2 cells on the hydrogel growthmatrices, as well as on the polyester filters (transwells), expressed the tight-junction protein zonula occludens-1 (ZO-1) at the cell-cell borders (Figure 2B). The Caco-2 cells grown on the hydrogel exhibited a slightly bumpy monolayer, and therefore appeared to have small holes in the layer, where cells were out of focus. The TEER value of Caco-2 cells grown on hydrogel growth-matrices increased over three weeks to a final value of $551 \pm 248 \Omega \mathrm{cm}^{-2}(\mathrm{mean} \pm \mathrm{SD}$, $\mathrm{n}=16)$. By contrast, Caco-2 cells grown on polyester filters reached $1585 \pm 159 \Omega \mathrm{cm}^{-2}$ 
$(\mathrm{mean} \pm \mathrm{SD}, \mathrm{n}=8$ ) (Figure 2C). TEER values for Caco-2 cells grown on soft growth-matrices such as collagen hydrogels have previously been reported in the range of $400-600 \Omega \mathrm{cm}^{-2} \cdot{ }^{[35,51]}$ Hence, the value reported here of $551 \Omega \mathrm{cm}^{-2}$ is in accordance with what has previously been reported for Caco-2 cells on soft growth-matrices. Caco-2 cells grown directly on filters, and these are known to have higher TEER values than corresponding cultures on soft growthmatrices. ${ }^{[52,53]}$ TEER values of Caco-2 cells on filters have been shown to be from $\sim 3$ times to $\sim 12$ times higher than in vivo small intestinal resistance that has been reported to be from 35 $60 \Omega \mathrm{cm}^{-2} \cdot{ }^{[53,54]}$ However, the TEER value is highly dependent on the measuring equipment used and consequently it is difficult to make a comparison. ${ }^{[55]}$

A

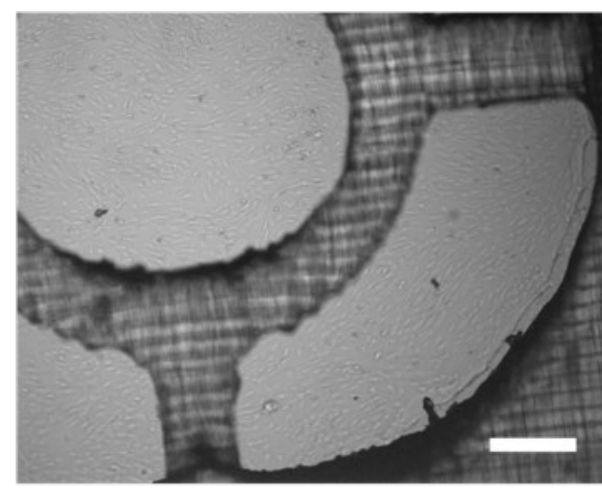

B

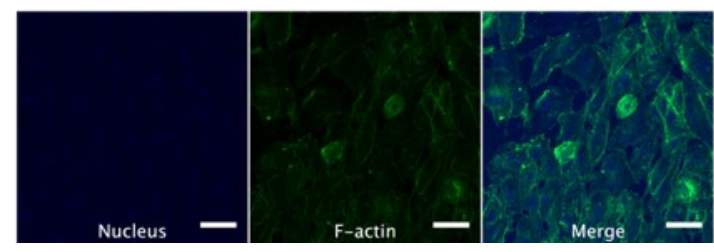

C

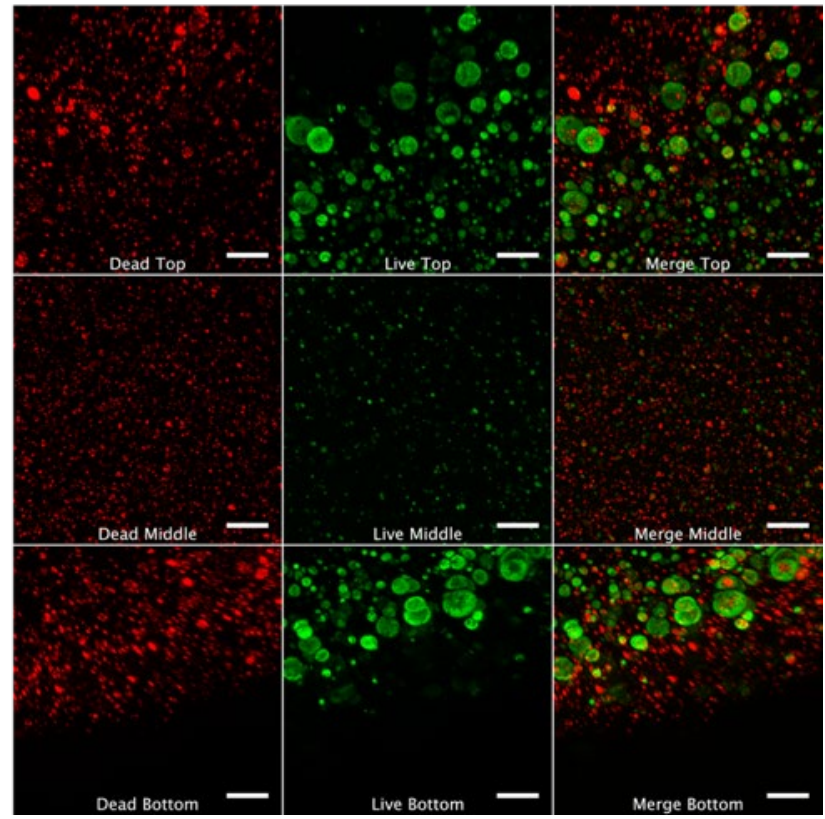

Figure 3. A) Bright-field microscopy of HUVEC cells on the hydrogel growth-matrix two days after seeding. Scalebar: 1000 $\mu \mathrm{m}$. B) F-actin (green) and nucleus (blue) stain of HUVEC cells on the hydrogel growth-matrix. Scalebars $50 \mu \mathrm{m}$. C) Stain of HepG2 cells grown for 20 days in the hydrogel growth-matrix. The live (green) and dead (red) distributions in the top, middle, and bottom of the hydrogel. Scalebars: $200 \mu \mathrm{m}$. 


\subsubsection{Characterization of the Endothelial Layer of HUVEC and the Hepatic Layer of HepG2}

cells

HUVEC cells have previously been grown in soft growth-matrices to obtain in vitro vascular networks. ${ }^{[56,57]}$ In the presented study, HUVEC cells were grown on top of a hydrogel growthmatrix to gain a vascular barrier. HUVEC cells were evenly distributed two days after seeding on the gelatin hydrogel (Figure 4A). Furthermore, HUVEC cells showed elongated profiles with clearly visible actin fibers (Figure 4B), which are the characteristics of blood vessel in vivo. However, the HUVEC cells did not display elongation to the same extent as what was seen previously under flow. ${ }^{[57]}$

HepG2 cells grown in 3D as spheroids has been shown to have a higher drug sensitivity than HepG2 cells grown as 2D cell-cultures. ${ }^{[58]}$ Hence, a 3D cell-culture would be better to detect adverse drug effects than a 2D culture. Therefore, the HepG2 cells were grown in 3D in the hydrogel growth-matrix in the presented system. Single entrapped HepG2 cells grew to large hepatic spheroids in the hydrogel growth-matrix over three weeks (Figure S5). The spheroids were largest close to the top and the bottom surfaces of the hydrogel growth-matrix, whereas in the middle of the hydrogel growth-matrix single dead hepatocytes were visible (Figure 3C). The stiffness of the hydrogel growth-matrix utilized for growth of the HepG2 cells was comparable to an in vivo liver, ${ }^{[41]}$ which has a Young's modulus (E) of approximately 300$600 \mathrm{~Pa} \cdot{ }^{[59,60]}$ HepG2 spheroids of $<200 \mu \mathrm{m}$ took 20 days of culture while spheroids $\geq 200 \mu \mathrm{m}$ took 27 days (Figure S5). Hepatocytes grown for 20 days were thought to be more suitable for metabolic and toxic studies, since spheroids $>200 \mu \mathrm{m}$ have been shown to have a hypoxic core due to insufficient oxygen diffusion. ${ }^{[46,61,62]}$

3D cultures have molecular gradients of nutrients and effector molecules, leading to different phenotypes of the cells located centrally and peripherally in the tissue. ${ }^{[31,46]}$ In the center of the hydrogel growth-matrix the hepatocytes did not grow most likely caused by lack 11 
of oxygen, since oxygen has a relatively low solubility in cell medium whereas gradients of glucose and amino acids are almost negligible. ${ }^{[46]}$ However, dead HepG2 cells were also seen close to the surface, where they were able to access oxygen and nutrients. This phenomenon was also observed with HepG2 cells entrapped in gelatin hydrogels with nutrient and oxygen coming from microfluidic channels through the hydrogel. ${ }^{[31]}$ While Pimentel et al. ${ }^{[31]}$ could not exclude artefacts from the sacrificial molding process, the data presented here suggest that cells could have died from competition with the large nearby spheroids for nutrients.

\subsection{Drug Transport Across the Triple Layered System}

\subsubsection{Permeability of the Triple Layered Transport System}

To assess the barrier function of the different tissue models lucifer yellow was utilized as a model compound. Cumulative transport fractions and permeability of lucifer yellow were measured across cell and hydrogel growth-matrices. The empty hydrogel growth-matrix and the empty polyester filters displayed similar lucifer yellow transport slopes (Figure 4A). However, the transport across the hydrogel growth-matrix displayed a delay compared to the polyester filter indicating that the hydrogel growth-matrix acted as a diffusion barrier. This was probably due to that the hydrogel growth-matrix was $1 \mathrm{~mm}$ thick whereas the polyester filter was $10 \mu \mathrm{m}$ thick. Confluent monolayers of Caco-2 cells both the hydrogel growth-matrices and polyester filters displayed a flat cumulative transported fraction slope (Figure 4A). From the cumulative transported fraction, the permeability of lucifer yellow across the different cell barriers was calculated. The barrier function of Caco-2 monolayers on the hydrogel growthmatrix was assessed by TEER measurements and compared to the lucifer yellow permeability.

A TEER value above $300 \Omega \mathrm{cm}^{-2}$ was determined as a tight layer because the permeability dropped approximately 14 times with TEER $>300 \Omega \mathrm{cm}^{-2}$ (Figure 4B). Presumably, because at this TEER value, the Caco-2 cells became a tight monolayer covering the whole hydrogel 12 
growth-matrix. Empty gelatin hydrogels and polyester filters displayed similar high permeabilities of $3.18 \times 10^{-5} \pm 4.74 \times 10^{-6} \mathrm{~cm} \mathrm{~s}^{-1}($ mean $\pm \mathrm{SD}, \mathrm{n}=8)$ and $3.90 \times 10^{-5} \pm 3.03 \times 10^{-6} \mathrm{~cm} \mathrm{~s}^{-1}$ (mean $\pm \mathrm{SD}, \mathrm{n}=9$ ), respectively (Figure $4 \mathrm{C}$ ). The permeability of the polyester filter was significantly more permeable to lucifer yellow ( $\mathrm{p}$-value $=0.34 \times 10^{-2}$ ), as mentioned above due to the thickness of the hydrogel growth-matrix. Caco-2 cells on hydrogel growth-matrices and polyester filters showed comparable low permeabilities of $1.22 \times 10^{-6} \pm 1.30 \times 10^{-6} \mathrm{~cm} \mathrm{~s}^{-1}$ $($ mean $\pm \mathrm{SD}, \mathrm{n}=8)\left(\right.$ for TEER values $\left.>300 \Omega \mathrm{cm}^{-2}\right)$ and $4.19 \times 10^{-7} \pm 2.77 \times 10^{-7} \mathrm{~cm} \mathrm{~s}^{-1}($ mean $\pm \mathrm{SD}$, $\mathrm{n}=15$ ), respectively. The permeability of lucifer yellow across Caco-2 monolayers on hydrogel growth-matrices and polyester filers was not found to significant ( $\mathrm{p}$-value $=0.13$ ). 
A

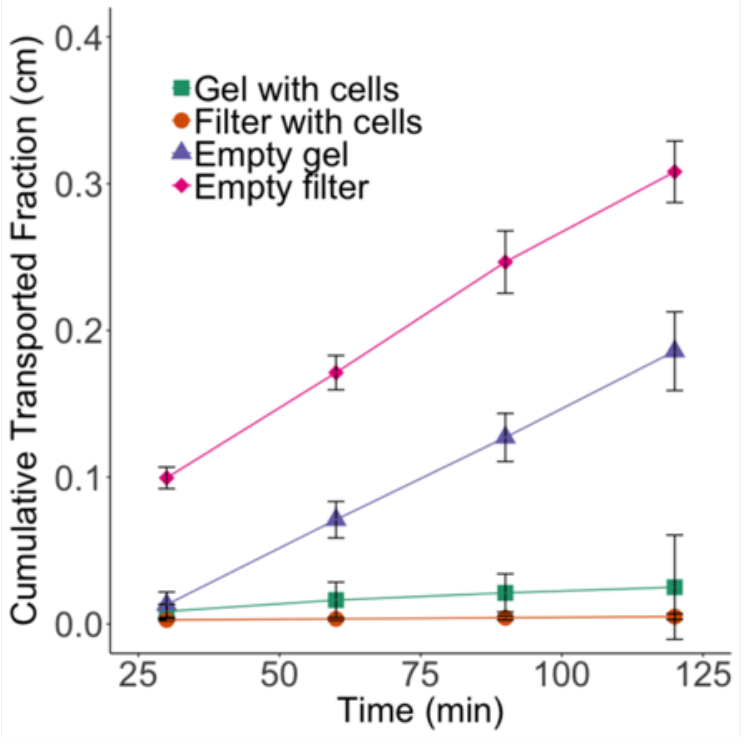

B

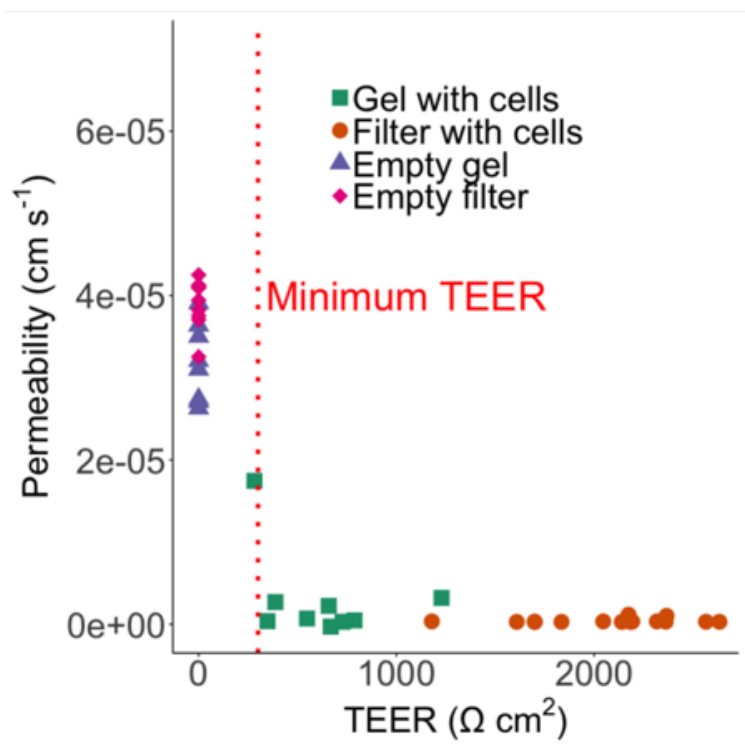

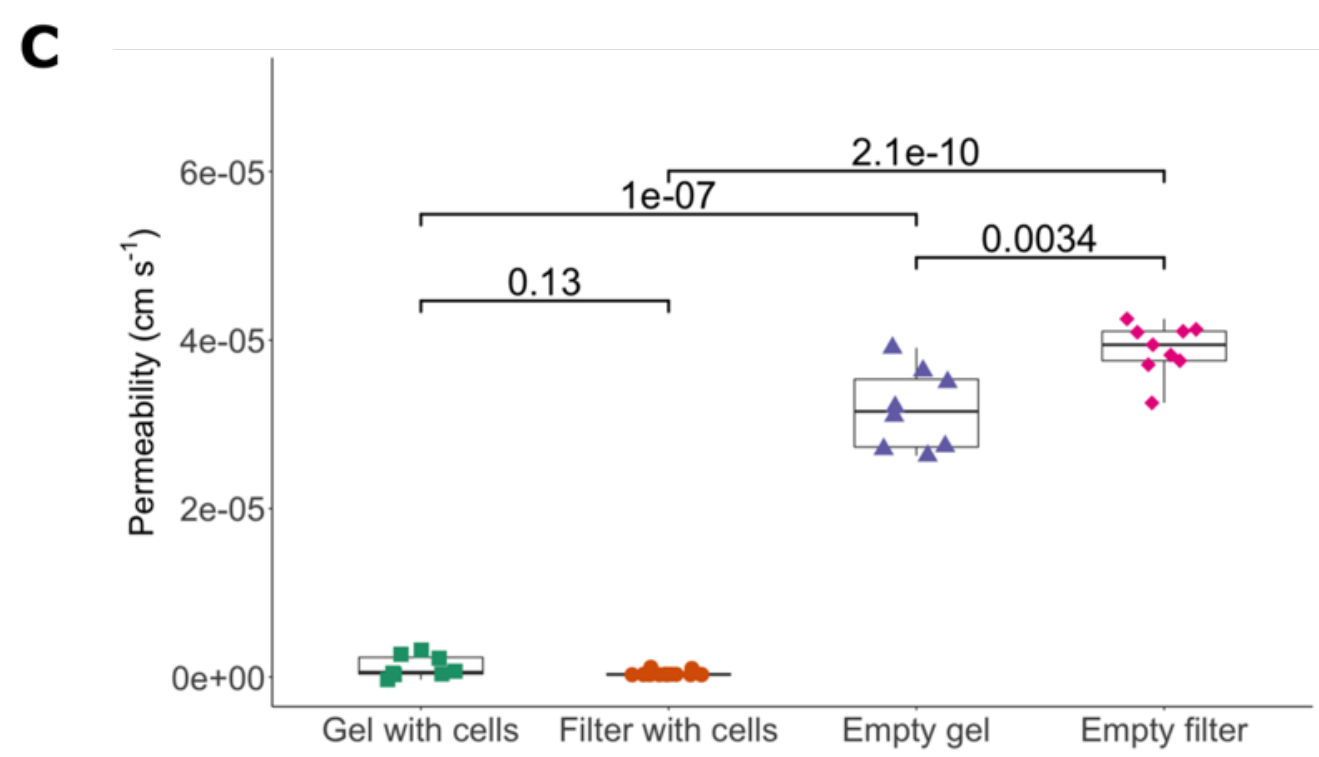

Figure 4: A) Cumulative transported fraction of lucifer yellow across Caco-2 cells on the hydrogel growth-matrix (mean $\pm \mathrm{SD}$, $\mathrm{n}=9$ ), empty hydrogel growth-matrices ( $m e a n \pm \mathrm{SD}, \mathrm{n}=8$ ), Caco-2 cells on polyester filters (mean $\pm \mathrm{SD}, \mathrm{n}=15$ ), and empty polyester filters (mean \pm SD, n=9). B) Permeability of lucifer yellow versus TEER . C) Permeability of lucifer yellow.

A Confluent HUVEC cell layer did not inhibit the transport of lucifer yellow across the hydrogel growth-matrix (Figure 5A). The permeability of HUVEC cells on the hydrogel growth-matrix was $2.09 \times 10^{-5} \pm 6.20 \times 10^{-6} \mathrm{~cm} \mathrm{~s}^{-1}$ (mean $\pm \mathrm{SD}, \mathrm{n}=7$ ) and the permeability for the empty gel was also $2.09 \times 10^{-5} \pm 9.52 \times 10^{-6} \mathrm{~cm} \mathrm{~s}^{-1}$ (mean $\pm \mathrm{SD}, \mathrm{n}=4$ ) (Figure 5B). This observation 
correlated with the non-measurable TEER value over the HUVEC layer. Both observations showed that the layer was leaky. This may, to some extent, model the fenestrated endothelial cells in liver sinusoids that ensure rapid transport of toxic compounds in the blood to the hepatocytes. ${ }^{[63]}$

The thicker gelatin hydrogel with entrapped HepG2 cells was a large diffusion barrier and no transport was observed with or without cells (Figure 5C). The thicker gelatin hydrogel with entrapped HepG2 cells showed a low lucifer yellow permeability of $1.40 \times 10^{-6} \pm 1.12 \times 10^{-6}$ $\mathrm{cm} \mathrm{s}^{-1}($ mean $\pm \mathrm{SD}, \mathrm{n}=9)$ with cells and $1.15 \times 10^{-6} \pm 1.08 \times 10^{-6} \mathrm{~cm} \mathrm{~s}^{-1}($ mean $\pm \mathrm{SD}, \mathrm{n}=8)$ without cells (Figure 5D). Hence, the liver compartment acted as a sponge for drugs that crossed the two other compartments. The spheroids did not act as a barrier as the difference between empty hydrogel growth-matrices and hydrogel growth-matrices containing HepG2 spheroids was not found to be significantly different ( $p$-value $=0.65$ ). A thinner layer or other gels allowing for higher diffusivity would increase mass transport in the system. 
A

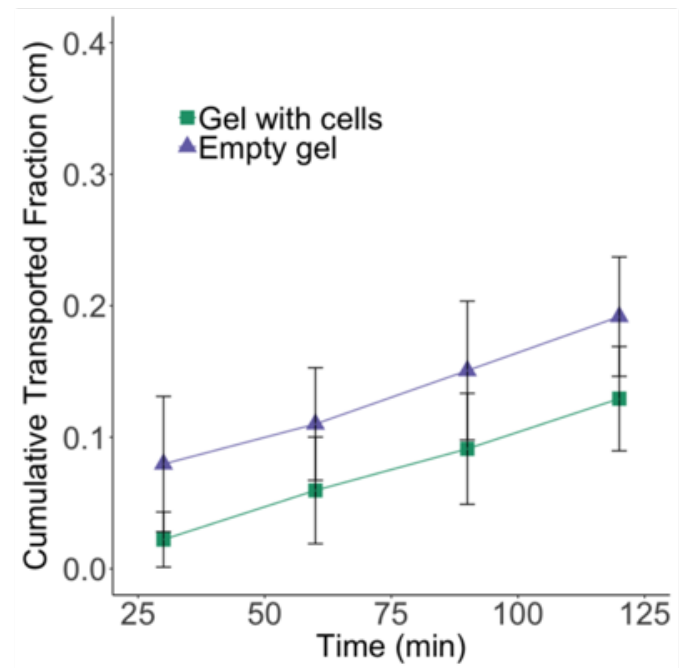

C

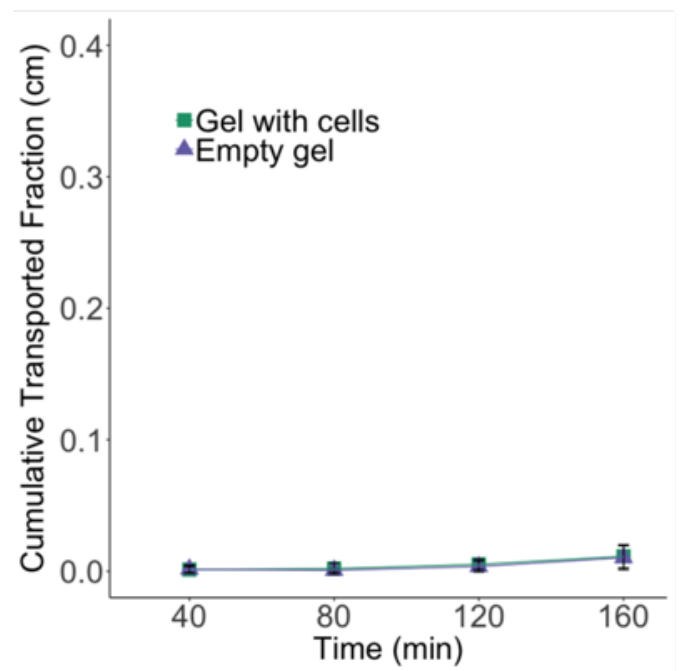

B

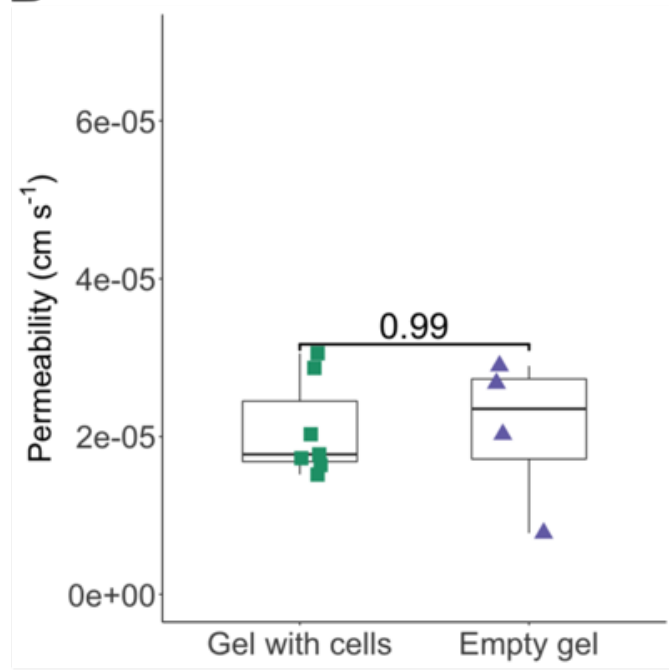

D

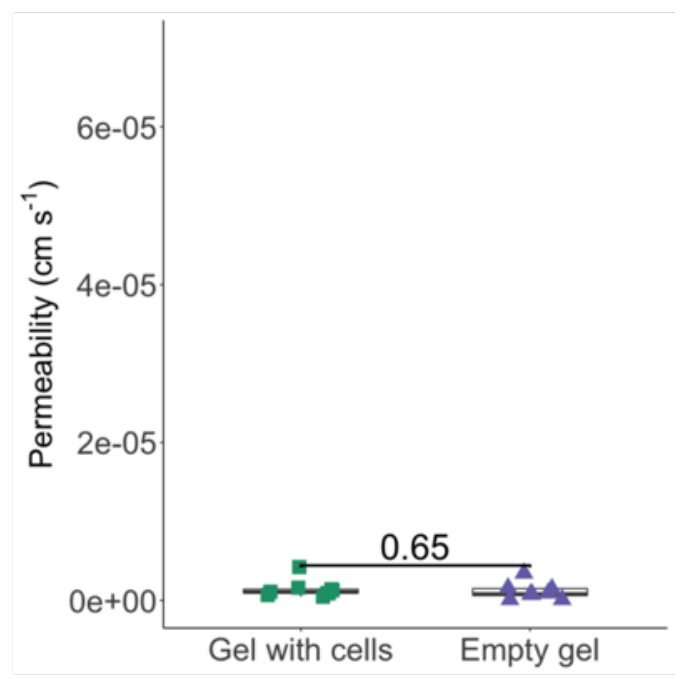

Figure 5: A) Cumulative transported fraction of lucifer yellow across HUVEC cells on the hydrogel growth-matrix (mean $\pm \mathrm{SD}$, $\mathrm{n}=7$ ) and empty hydrogel growth-matrices (mean $\pm \mathrm{SD}, \mathrm{n}=4$ ). B) Permeability of lucifer yellow across HUVEC cells on the hydrogel growth-matrix and empty hydrogel growth-matrices. C) Cumulative transported fraction of lucifer yellow across HepG2 cells on the hydrogel growth-matrix (mean $\pm \mathrm{SD}, \mathrm{n}=9)$ and empty hydrogel growth-matrices (mean $\pm \mathrm{SD}, \mathrm{n}=8) . \mathrm{D})$ Permeability of lucifer yellow across HepG2 cells on the hydrogel growth-matrix and empty hydrogel growth-matrices.

\subsubsection{Transport of Furosemide and Valacyclovir Across Intestinal Caco-2 Tissue Model}


Furosemide was used as a model drug to show the Caco-2 monolayer as a barrier on the hydrogel (Figure 6A). Furosemide is a poorly absorbed drug and can be used to compare the barrier function of the presented method with the in vivo situation. ${ }^{[64]}$

The permeability of furosemide across the Caco-2 cells on the hydrogel growth-matrix was $1.53 \times 10^{-6} \pm 3.34 \times 10^{-7} \mathrm{~cm} \mathrm{~s}^{-1}($ mean $\pm \mathrm{SD}, \mathrm{n}=6)$, whereas the permeability across the empty hydrogel growth-matrix was $2.06 \times 10^{-5} \pm 1.62 \times 10^{-6} \mathrm{~cm} \mathrm{~s}^{-1}($ mean $\pm S D, n=5)\left(p\right.$-value $\left.=5.7 \times 10^{-6}\right)$ (Figure 6B). This is in accordance with what $\mathrm{Li}$ et al. observed, as they reported a furosemide permeability of $1.3 \times 10^{-6} \mathrm{~cm} \mathrm{~s}^{-1}$ across a Caco-2 layer. ${ }^{[65]}$ Pade et al. showed a furosemide permeability of $1.2 \times 10^{-7} \mathrm{~cm} \mathrm{~s}^{-1}$ at $\mathrm{pH} 7.2$ across Caco-2 cells on filters, ${ }^{[6]}$ and Hilgendorf et al. showed a furosemide permeability of $2.9 \times 10^{-7} \mathrm{~cm} \mathrm{~s}^{-1}$ at $\mathrm{pH} 6.5$ across Caco-2 cells on filters. ${ }^{[67]}$ Nielsen et al. showed a permeability of $8.63 \times 10^{-6} \mathrm{~cm} \mathrm{~s}^{-1}$ with an apical $\mathrm{pH}$ of 7.4 and basolateral $\mathrm{pH}$ of $6.5,{ }^{[68]}$ and Rege et al. reported $6.8 \times 10^{-7} \mathrm{~cm} \mathrm{~s}^{-1}$ with $\mathrm{pH} 6.8$ both apically and basolaterally. ${ }^{[69]}$

The higher permeability of furosemide over the Caco-2 cell layer on the hydrogel growth-matrix compared to filters reported in literature was consistent with higher lucifer yellow permeability of cells on gels compared to cell on filter (see above). Another explanation could be that the Caco- 2 cells on the hydrogel growth-matrices do not to express the efflux pump P-glycoprotein, of which furosemide is a substrate, ${ }^{[70]}$ to the same extent as Caco-2 cells on the polyester filter. The lower TEER values (Figure 2C) indicated that the increased permeability of the Caco- 2 cells on the hydrogel growth-matrix was caused by a less tight cell layer compared to Caco-2 cells on a filter. On the other hand, the permeability of furosemide across the small intestine rat intestine ex vivo was shown to be $6.36 \times 10^{-7} \mathrm{~cm} \mathrm{~s}^{-1},{ }^{[70]}$ or little more than two fold lower compared to the Caco-2 on the hydrogel growth-matrix. Hence, the 
presented setup might be closer to the in vivo situation than Caco-2 cells grown on polyester filters.

A

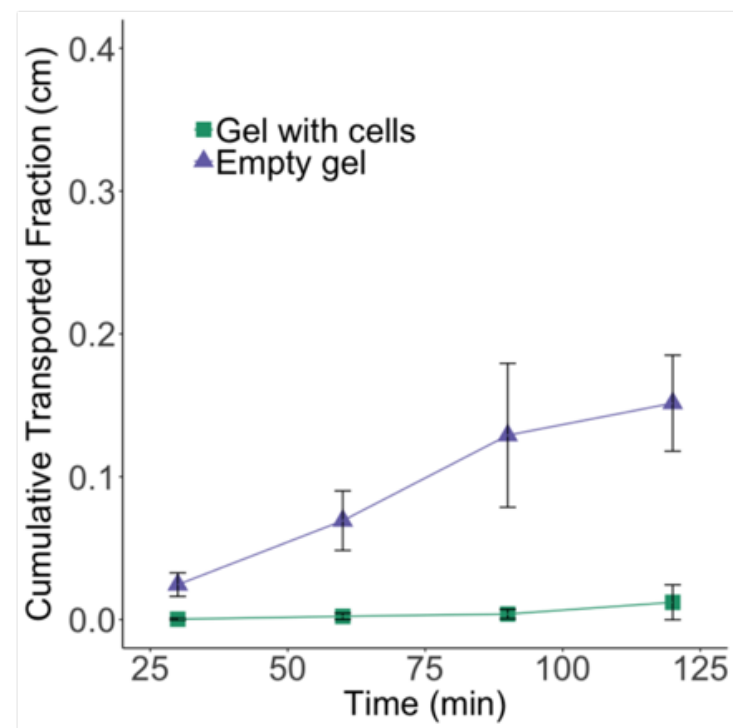

B

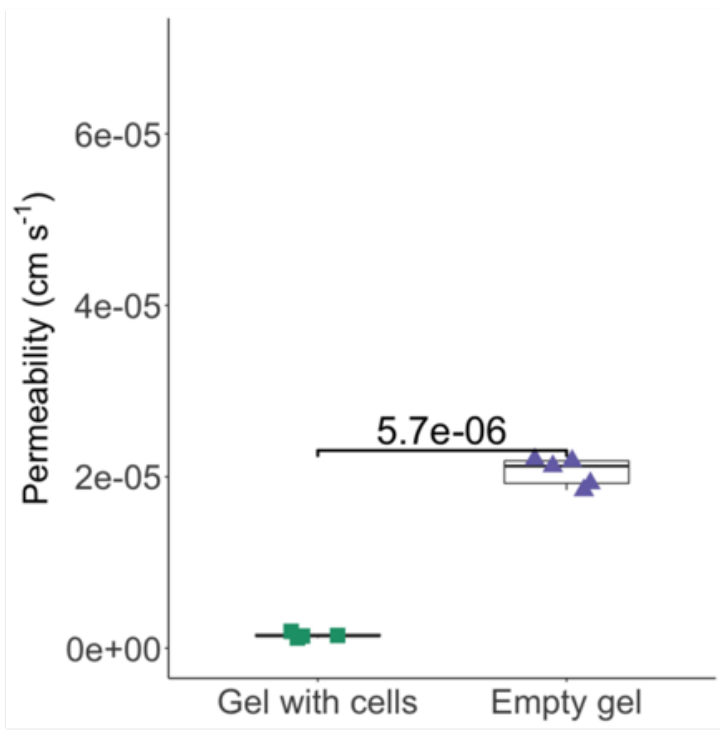

Figure 6: A: Cumulative transported fraction of furosemide across Caco-2 cells on the hydrogel growth-matrix (mean \pm SD, $\mathrm{n}=4$ ) and empty hydrogel growth-matrices (mean $\pm \mathrm{SD}, \mathrm{n}=5$ ). B: cells on the hydrogel growth-matrix and empty hydrogel growth-matrices.

To show that the Caco-2 cell model was tight paracellularly, prodrugs were utilized to investigate another type of drug transport. Prodrugs are drugs given in inactive forms that can be activated in the body often with the purpose of improving absorption. ${ }^{[71]}$ Valacyclovir is a prodrug derived from acyclovir with incorporation of a valine group making it a substrate for the hPepT1 transporter of enterocytes in the small intestine. ${ }^{[72]}$ Transport of valacyclovir and acyclovir across an empty hydrogel growth-matrix was $9.80 \pm 1.23 \%,($ mean $\pm \mathrm{SD}, \mathrm{n}=4)$ and $11.55 \pm 0.70 \%($ mean $\pm \mathrm{SD}, \mathrm{n}=4)$ over $4 \mathrm{~h}$, respectively (Figure $7 \mathrm{~A})$. On the hydrogel growthmatrix with a confluent Caco-2 monolayer, no transport of valacyclovir was detectable due to a fast conversion to acyclovir resulting in it no longer being a substrate for hPepT1 (Figure 7B). $83.99 \pm 2.39 \%($ mean $\pm \mathrm{SD}, \mathrm{n}=4)$ of valacyclovir was degraded to acyclovir in the presence of Caco- 2 cells on the gel over $4 \mathrm{~h}$, whereas only $40.27 \pm 2.70 \%$ (mean $\pm \mathrm{SD}, \mathrm{n}=4)$ was converted 18 
on top of an empty gel. Since, Caco-2 cells are known to express carboxylesterases which convert valacyclovir to acyclovir, ${ }^{[73]}$ this indicates that the Caco-2 cells differentiate to tight monolayers with expression of metabolic enzymes.

A

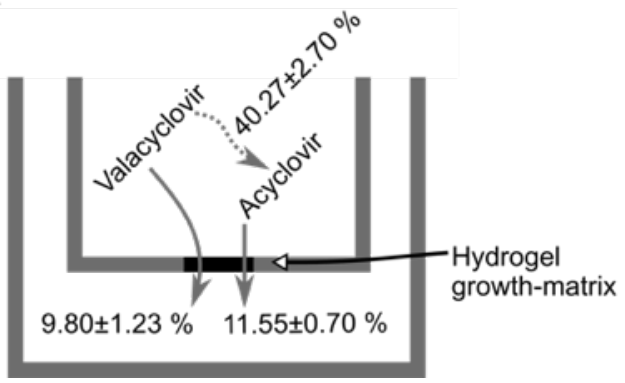

B

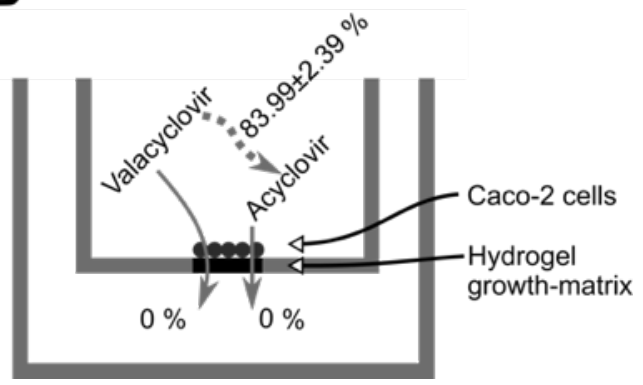

Figure 7: A: Transport of valacyclovir and acyclovir across the empty hydrogel growth-matrix (mean $\pm \mathrm{SD}, \mathrm{n}=4)$. B: Transport of valacyclovir and acyclovir across Caco-2 cells on the hydrogel growth-matrix (mean $\pm \mathrm{SD}, \mathrm{n}=4$ ). Hydrogels are shown in pink and Caco-2 cells in blue.

\section{Conclusion}

We report on a 3D-printed triple interconnected in vitro tissue method, which is cheap and easy to produce and does not rely on tubes and pumps used in microfluidic systems. The presented method can support various cell types of both hollow and solid tissues. Each individual cell culture can mature independently, and subsequently be connected for a transport study. In this way, medium incompatibility is avoided and each cell line can grow optimally. The method allows for both observing the cell culture growth with bright-field microscopy and end point staining and confocal microscopic characterization.

We present a method for simulating the first pass metabolism in vitro. This was done by observing intestinal drug transport via a blood compartment to a liver compartment with sampling in each individual compartment. Here, it was shown that the permeability of the intestinal Caco-2 layer was similar to that observed in vivo but different from that of Caco-2 on a polystyrene filter. The system is compact and flexible and can be scaled to connect different tissue models. The system can be adjusted to the need of lower or higher cells amount, drug, 19 
and signal molecule. It is of interest to test longer studies for transport and other applications. However, medium incompatibilities and direct cross talk between cell layers need to be carefully considered and characterized.

\section{Experimental Section}

\subsection{Materials}

Dental LT resin (Dental LT FLDCL01) was obtained from Formlabs, Inc. (Somerville, Massachusetts, USA). High-glucose DMEM, trypsin-ethylenediaminetetraacetic acid (EDTA) solution $\left(0.5 \mathrm{~g} \mathrm{~L}^{-1}\right.$ porcine trypsin and $0.2 \mathrm{~g} \mathrm{~L}^{-1}$ EDTA-4Na), ECGM, Penicillin-Streptomycin (P/S), phosphate-buffered saline (PBS, D8537), RPMI 1640 medium, gelatin, Hoechst 33342 trihydrocloride trihydrate, triton X-100, 4-(2-hydroxyethyl)-1-piperazineethanesulfonic acid (HEPES), sodium bicarbonate, and bovine serum albumin (BSA) were all obtained from SigmaAldrich (Broendby, Denmark). Non-essential amino acids (NEAA), ZO-1 Rabbit Polyclonal antibody, Goat anti-Rabbit IgG $(\mathrm{H}+\mathrm{L})$ Superclonal Secondary Antibody - Alexa Flour ${ }^{\circledR} 488$ conjugate, Alexa Flour $^{\mathrm{TM}} 594$ Phalloidin, LIVE/DEAD ${ }^{\mathrm{TM}}$ Viability/Cytotoxicity Kit (L3224), Hank's Balanced Salt Solution (HBSS (10X), 12 well Transwell ${ }^{\circledR}$ inserts (pore size $0.4 \mu \mathrm{m}$ ) (Corning), and lucifer yellow (Invitrogen ${ }^{\mathrm{TM}}$ ) was purchased from Thermo Fisher Scientific (Slangerup, Denmark). Fetal bovine serum (FBS) was obtained from Biowest, SAS (Nuaillé, France), and T-75 cell culture flasks were purchased from Starstedt (Nümbrecht, Germany). Human epithelial colon carcinoma (CACO-2 (ECACC 09042001)) cells were acquired from European Collection of Authenticated Cell Cultures (Salisbury, Great Britain), whereas the HUVEC cell line was bought from Cell Applications, Inc. (San Diego, California, United States). Human hepatoma (HepG2) cells were obtained from the European Collection of Authenticated Cell Cultures (ECACC) through Sigma-Aldrich (Broendby, Denmark). 20 
Paraformaldehyde (16 \%) was purchased from Electron Microscopy Sciences (Pensylvania, United States). Activa TI tranglutaminase was obtained from Ajinomoto Food Ingredients LLC (Chicago Illinois, USA). Furosemide ( $>98 \%$ purity) was purchased from Fagron Nordic (Copenhagen, Denmark), whereas valacyclovir and acyclovir were obtained from TCI Europe N.V. (Zwijndrecht, Belgium).

\subsection{Cell Lines and Growth}

Caco-2 cells (passage 40-75) were cultured in T-75 cell culture flasks (Starstedt, Nümbrecht, Germany) in Dulbecco's DMEM medium with FBS (20\% (v/v)), NEAA (1 \% (v/v)), and P/S (100 $\mathrm{U} \mathrm{mL}^{-1}$ penicillin and $100 \mu \mathrm{g} \mathrm{mL}^{-1}$ streptomycin). HUVEC cells (passage $3-12$ ) were cultured in endothelial culture medium FBS $(10 \%(\mathrm{v} / \mathrm{v}))$, and $\mathrm{P} / \mathrm{S}\left(100 \mathrm{U} \mathrm{mL}^{-1}\right.$ penicillin and $100 \mu \mathrm{g} \mathrm{mL} \mathrm{m}^{-1}$ streptomycin). HepG2 cells (passage 100-130) were cultured in RMPI 1640 medium FBS $(10 \%(\mathrm{v} / \mathrm{v}))$, and $\mathrm{P} / \mathrm{S}\left(100 \mathrm{U} \mathrm{mL}^{-1}\right.$ penicillin and $100 \mu \mathrm{g} \mathrm{mL} \mathrm{L}^{-1}$ streptomycin $)$. All the cells were cultured at $37^{\circ} \mathrm{C}$ and $5 \% \mathrm{CO}_{2}$ and split with trypsin-EDTA for 5-10 min upon $80-90 \%$ confluency. Once the cells were detached, trypsin-EDTA were inhibited by addition of cell culture medium, and a sample was taken for counting the cells (counted with NucleoCounter NC-200).

\subsection{Fabrication of 3D-printed inserts}

3D designs were drawn using Fusion 360 (version 1.28.2, Autodesk, San Rafael, California, USA) and print files were exported in STL format and processed in PreForm (version 2.12.0, Formlabs, Somerville, Massachusetts, USA) (Figure S2). 3D designs were printed on a Formlabs Form 2 3D printer (Formlabs, Somerville, Massachusetts, USA).

3D prints for cell cultures were printed in Dental LT resin with a layer thickness of 0.1 $\mathrm{mm}$, and were subsequently cleaned twice in fresh isopropyl alcohol for $1 \mathrm{~h}$ and air dried 21 
overnight. The 3D prints were cured in a Formlabs Form Cure UV-oven (Formlabs, Somerville, Massachusetts, USA) for $2 \mathrm{~h}$ at $60{ }^{\circ} \mathrm{C}$, after which the support structures were cut off followed by submersion in sterile water for a day. Once the prints were dry, a further 15 min cure at $60{ }^{\circ} \mathrm{C}$ for sterilization was performed.

Parts for the casting device were printed using a Prusa i3 MK3 3D printed with a 0.4 mm nozzle, a layer height of $0.2 \mathrm{~mm}$ and $15 \%$ infill from PLA filament. Small springs were placed on the pillars on the board and the plugs coated with parafilm were put on the springs (Figure S3A).

\subsection{Casting of Hydrogels and Seeding of Cells}

For casting of hydrogel growth-matrices into, the 3D-printed inserts and casting device were assembled (Figure S3). Once assembled, $30 \mu \mathrm{L}$ (for Caco-2 and HUVEC inserts) or 100 $\mu \mathrm{L}$ (for HepG2 inserts) of a mixture of gelatin $(5 \% \mathrm{w} / \mathrm{v})$ and $\mathrm{mTG}\left(5 \mathrm{U} \mathrm{mL}^{-1}\right.$ for Caco-2 and HUVEC or $2.5 \mathrm{U} \mathrm{mL}^{-1}$ for HepG2) was added. The hydrogel growth-matrix was crosslinked for $1 \mathrm{~h}$ at $37^{\circ} \mathrm{C}$. Afterwards, the 3D-printed insert was removed from the casting device. Either $10^{6}$ cells $\mathrm{mL}^{-1}$ of HepG2 cells were seeded into the hydrogel growth-matrix while casting, or Caco-2 and HUVEC cells were seeded on top of the hydrogel growth-matrix after casting. 100,000 Caco-2 cells were seeded onto each hydrogel growth-matrix in the 3D-printed inserts corresponding to $\sim 155,000$ cells $\mathrm{cm}^{-2}$, whereas polyester filters were seeded with $\sim 140,000$ Caco-2 cells corresponding to $\sim 125,000$ cells $\mathrm{cm}^{-2}$. Both seedings were within the recommended density. ${ }^{[74]}$ The apical medium was changed between 4 and $16 \mathrm{~h}$ after seeding. In the HUVEC inserts, 200,000 HUVEC cells were also seeded onto each hydrogel growthmatrix. $1 \mathrm{~mL}$ medium was added on top and below the hydrogel growth-matrix with HepG2 cells. $500 \mu \mathrm{L}$ was added on top and $1 \mathrm{~mL}$ below hydrogel growth-matrices with Caco-2 and 
HUVEC cells. The Caco-2 and HepG2 cells were cultured for three weeks with the medium exchanged two times a week. The HUVEC cells were seeded two days before use.

After use, the gelatin hydrogels could be dissolved by the use of trypsin which then made it possible to reuse the $3 \mathrm{D}$ printed parts without decreasing the performance of the inserts.

\subsection{Staining of F-actin, Live/Dead, and ZO-1 Stains}

For F-actin staining, samples were washed for $15 \mathrm{~min}$ in PBS followed by fixation in 3 \% PFA in PBS for $30 \mathrm{~min}$ at room temperature. PFA was aspirated from the samples and the samples were incubated with $0.05 \%$ Saponin $/ 1 \%$ BSA in PBS for $30 \mathrm{~min}$ at room temperature. The samples were washed three times in PBS and incubated with phalloidin stain $(5 \mu \mathrm{L}$ diluted in $200 \mu \mathrm{L}$ PBS) for $20 \mathrm{~min}$ at room temperature. The samples were washed three times in PBS and left in PBS.

For ZO-1 staining, cells were washed for $15 \mathrm{~min}$ in PBS followed by fixation in $3 \%$ PFA in PBS for 30 min at room temperature. PFA was aspirated and the samples were incubated in $3 \%$ BSA in PBS for 15 min at room temperature. Afterwards, the samples were washed three times in PBS and incubated with $5 \mu \mathrm{g} / \mathrm{mL}$ primary antibody in PBS with $0.1 \%$ Triton $\mathrm{X}-100$ for $1 \mathrm{~h}$ at room temperature. This was followed by three washes in PBS. The secondary antibody in PBS (1:1000) with $0.1 \%$ Triton X-100 was added and incubated for $1 \mathrm{~h}$ at room temperature. The samples were then washed three times in PBS and left in PBS.

For nuclei staining, samples were washed three times with PBS and $1 \mu \mathrm{g} \mathrm{mL} L^{-1}$ Hoechst 33342 in PBS was added and incubated for 10 min at room temperature. The samples were then washed three times in PBS and left in PBS.

For live/dead staining, the hydrogel growth-matrices were cut out of the 3D-printed inserts and cut in half length wise. Subsequently, the samples were washed three times in PBS and stain in $500 \mu \mathrm{L}$ of a solution with ethidium homodimer-1 $(8 \mathrm{nM})$ and calcein $(4 \mathrm{mM})$ for 1 23 
$\mathrm{h}$ at room temperature. The samples were washed in PBS two times and then kept in $200 \mu \mathrm{L}$ PBS to keep the hydrogel growth-matrices moisturized.

\subsection{Confocal Microscopy F-actin, Live/Dead, and ZO-1 Stains}

Confocal micrographs were obtained using a LSM 700 scanning confocal microscope (Carl Zeiss MicroImaging GmbH, 37081 Gottingen, Germany) with the following objectives; EC Epiplan-NEOFLUAR 10x/0.25 HD, EC Epiplan-NEOFLUAR 5x/0.13 HD, and EC EpiplanNEOFLUAR 10x/0.5 HD. $100 \mu \mathrm{L}$ of PBS was added around the hydrogel growth-matrices when performing microscopy to keep them moisturized. The obtained confocal micrographs were fitted with scalebars and Z-stacks were processed in Fiji by Z-projections of maximum intensities. ${ }^{[75]}$

Phase contrast bright-field micrographs were obtained using a Ziess Primovert microscope (Carl Zeiss MicroImaging GmbH, 37081 Gottingen, Germany) with the following objective: Plan-Achromat $4 \mathrm{x} / 0.10$. The obtained micrographs were fitted with scalebars in Fiji. ${ }^{[75]}$

\subsection{Transport Studies of, Lucifer Yellow, Furosemide, and Valacyclovir}

\subsubsection{TEER measurements}

An EVOM2 epithelial Volt/Ohm meter (World Precision Instruments, Sarasota, Florida, USA) was used to assess the resistance between the apical and the basolateral surfaces on confluent cell monolayers. The resistance of the monolayers was corrected by subtracting the resistance of an average $(\mathrm{n}=3)$ from blank wells without cells:

$R_{\text {sample }}-R_{\text {blank }}=R_{\text {cell layer }}(1)$

To normalize the resistance to the area, the area was multiplied by the resistance to obtain resistance values in $\Omega \mathrm{cm}^{2}$. The area of the hydrogel growth-matrix was $0.2 \mathrm{~cm}^{2}$ and the area 24 
of the commercial 12 well transwell plates was $1.13 \mathrm{~cm}^{2}$. From the TEER study over time, an average blank was obtained to be $130 \Omega \mathrm{cm}^{2}$ for conventional transwells and $160 \Omega \mathrm{cm}^{2}$ for hydrogel transwells.

\subsubsection{Lucifer Yellow Transport}

The three 3D-printed inserts were assembled for transport studies with lucifer yellow. Each compartment had $1 \mathrm{~mL}$ of preheated (to $37^{\circ} \mathrm{C}$ ) HBSS transport buffer (HBSS (1X), Sodium bicarbonate $(0.0375 \% \mathrm{w} / \mathrm{v})$, HEPES $(10 \mathrm{mM})$, BSA ( $0.05 \% \mathrm{w} / \mathrm{v}, \mathrm{pH} 7.4)$ while the transport study was performed at $37{ }^{\circ} \mathrm{C}$ with 100 rounds per minute (rpm) shaking. $2.25 \mu \mathrm{M}$ lucifer yellow was added apically of the tissue model which transport across was investigated. The transport study was performed for $2 \mathrm{~h}$ for Caco-2 and HUVEC cells and $3 \mathrm{~h}$ HepG 2 cells. Samples of $50 \mu \mathrm{L}$ were taken and $50 \mu \mathrm{L}$ HBSS transport buffer was added every 30 min for Caco-2 and HUVEC cells and 40 min HepG2 cells. After the transport experiment, the samples were measured with a TECAN spark plate reader by using an excitation of $428 \mathrm{~nm}$ and measuring emission at $536 \mathrm{~nm}$.

\subsubsection{Furosemide Transport through the Caco-2 cells}

The three 3D-printed inserts were assembled for transport studies with furosemide. Each compartment had $1 \mathrm{~mL}$ of preheated (to $37^{\circ} \mathrm{C}$ ) HBSS transport buffer while the transport study was performed. $0.75 \mathrm{mg} \mathrm{mL}^{-1}$ furosemide was added to the apical compartment. The transport study was performed for $4 \mathrm{~h}$ at $37^{\circ} \mathrm{C}$. Samples of $50 \mu \mathrm{L}$ were taken and $50 \mu \mathrm{L}$ HBSS transport buffer every $30 \mathrm{~min}$ for the first $2 \mathrm{~h}$ and every $60 \mathrm{~min}$ for the last $2 \mathrm{~h}$. HPLC analysis was performed of the samples just after the experiments following a previous established method, ${ }^{[76]}$ with slight differences. The HPLC analysis was performed on a Shimadzu HPLC system consisting of a CBM-20A system controller, SIL-20AC HT auto sampler, LC-20AD pump, 25 
DGU-20A5R degassing unit, CTO-20AC column oven, RID-20A refractive index detector, and SPD-30A photodiode array detector. A Phenomenex Kinetex ${ }^{\circledR} \mathrm{C} 18$ column $(100 \times 4.6 \mathrm{~mm}, 5$ $\mu \mathrm{m})$ was used, whereas the mobile phase consisted of purified water, methanol and phosphoric acid in a ratio of 49:50:1 v/v/v. The injection volume was $10 \mu \mathrm{L}$ with a flow rate of $0.7 \mathrm{~mL} / \mathrm{min}$ and a temperature of $25^{\circ} \mathrm{C}$. The furosemide content of the samples was identified using UV detection at a wavelength of $254 \mathrm{~nm}$.

\subsubsection{HPLC of valacyclovir and acyclovir}

The three 3D-printed inserts were assembled for transport studies with valacyclovir and acyclovir. Each compartment had $1 \mathrm{~mL}$ of preheated (to $37^{\circ} \mathrm{C}$ ) HBSS transport buffer while the transport study was performed. $0.5 \mathrm{mg} \mathrm{mL}^{-1}$ valacyclovir was added to the apical compartment. The transport study was performed for $4 \mathrm{~h}$ at $37^{\circ} \mathrm{C}$. Samples of $50 \mu \mathrm{L}$ were taken and $50 \mu \mathrm{L}$ HBSS transport buffer every $30 \mathrm{~min}$ for the first $2 \mathrm{~h}$ and every $60 \mathrm{~min}$ for the last $2 \mathrm{~h}$. Valacyclovir and acyclovir samples were analyzed using the same HPLC protocol as for furosemide. However, the mobile phase consisted of PBS at $\mathrm{pH} 5$ and methanol in a ratio of 75:25 v/v. ${ }^{[77]}$ The injection volume was $10 \mu \mathrm{L}$ with a flow rate of $0.7 \mathrm{~mL} \mathrm{~min}^{-1}$ and a temperature of $40^{\circ} \mathrm{C}$. The valacyclovir/acyclovir content of samples was identified using UV detection at a wavelength of $254 \mathrm{~nm}$.

\subsubsection{Calculation of Transport Rates}

From transport studies with the triple layered tissue models the cumulative transported fraction and the permeability were calculated by the following equations. Where, "a" refers to the compartment above the Caco-2 layer, "b" to the compartment above the HUVEC layer, "c" is the compart above the HepG2 layer, and " $\mathrm{d}$ " is the compartment below the HepG2 layer. 
Transport Across the Intestinal layer

The donor concentration for drug transport a to $\mathrm{b}$ was calculated by:

$C_{D}(t)=C_{D}\left(t_{i-1}\right)-\frac{\left[C_{R}(t)-f \times C_{R}\left(t_{i-1}\right)\right] \times V_{R}}{V_{D}}(2)$

Where, $V_{R}$ is the receiver volume, $V_{D}$ is the donor volume, $C_{R}(t)$ is the receiver concentration at the timepoint the donor concentration is being determined for, and $\mathrm{f}$ is defined by:

$f=1-\frac{V_{S}}{V_{R}}(3)$

Where, $\mathrm{V}_{\mathrm{S}}$ is the sampling volume. The receiver concentration was calculated from the concentrations in each compartment at a given time:

$C_{R}(t)=\frac{[b(t)] \times V_{R}+[c(t)] \times V_{R}+[d(t)] \times V_{R}}{V_{R}}(4)$

The cumulative transported fraction was calculated from the donor and receiver concentrations with the following equation:

$\operatorname{CTF}(t)=\frac{1}{A} \times \sum_{k=1}^{i} \frac{\left[C_{R}\left(t_{k}\right)-f \times C_{R}\left(t_{k-1}\right)\right] \times V_{R}}{\left[C_{D}\left(t_{k-1}\right)+C_{D}\left(t_{k}\right)\right] / 2}(5)$

Where, A is the area of the barrier. A linear curve fit of the cumulative transported fraction gives the permeability coefficient.

The receiver concentration was corrected for calculating basolateral to apical flow:

$C_{R}(t)=[a(t)](6)$

\section{Transport Across the Endothelial Layer}

The donor concentration for drug transport from $b$ to $c$ was calculated by:

$C_{D}(t)=C_{D}\left(t_{i-1}\right)-\frac{\left[C_{O}(t)-f \times C_{O}\left(t_{i-1}\right)\right] \times V_{R}}{V_{D}}(7)$

Where $\mathrm{C}_{\mathrm{O}}$ is the total concentration in the other compartments at a given time calculated by:

$C_{O}(t)=\frac{[a(t)] \times V_{R}+[c(t)] \times V_{R}+[d(t)] \times V_{R}}{V_{R}}(8)$ 
The receiver concentration was calculated from the concentrations in the receiving compartments $\mathrm{c}$ and $\mathrm{d}$ :

$C_{R}(t)=\frac{[c(t)] \times V_{R}+[d(t)] \times V_{R}}{V_{R}}(9)$

The cumulative transported fraction was calculated from the receiver and donor concentration using equation (5) and the permeability coefficient was obtained from the curve of the cumulative transported fraction.

The receiver concentration was corrected for calculating basolateral to apical flow:

$C_{R}(t)=\frac{[a(t)] \times V_{R}+[b(t)] \times V_{R}}{V_{R}}(10)$

Transport Across the Hepatic Layer

The donor concentration for drug transport from $\mathrm{c}$ to $\mathrm{d}$ was calculated by equation (7), where $\mathrm{C}_{\mathrm{O}}$ is calculated by:

$C_{O}=\frac{[a(t)] \times V_{R}+[b(t)] \times V_{R}+[d(t)] \times V_{R}}{V_{R}}(11)$

The receiver concentration was calculated from the concentrations in the receiving compartment $\mathrm{d}$ at a given time:

$C_{R}(t)=[d(t)](12)$

From the receiver and donor concentration, the cumulative transported fraction was calculated using equation (5) and the permeability coefficient was obtained from the curve of the cumulative transported fraction.

\subsection{Statistical analysis}

The data are presented as sample size (n), mean \pm SD. Calculations were done using RStudio (Version 1.2.5001, RStudio, Inc.) and Microsoft Excel (Version 15.41, Microsoft Office, 
Seattle, Washington). P-values were obtained using a Two sample T-test and determined significant different when $p$-value $<0.05$.

Supporting Information ((delete if not applicable))

Supporting Information is available from the Wiley Online Library or from the author.

\section{Acknowledgements}

The authors would like to acknowledge the Danish National Research Foundation (DNRF122) and Villum Fonden (Grant No. 9301) for Intelligent Drug Delivery and Sensing Using Microcontainers and Nanomechanics (IDUN).

Received: ((will be filled in by the editorial staff))

Revised: ((will be filled in by the editorial staff)) Published online: ((will be filled in by the editorial staff))

\section{References}

[1] P. V. Balimane, S. Chong, R. A. Morrison, J. Pharmacol. Toxicol. Methods 2000, 44, 301.

[2] P. Colombo, F. Sonvico, G. Colombo, R. Bettini, Pharm. Res. 2009, 26, 601.

[3] M. Dickson, J. P. Gagnon, Nat. Rev. Drug Discov. 2004, 3, 417.

[4] S. M. Paul, D. S. Mytelka, C. T. Dunwiddie, C. C. Persinger, B. H. Munos, S. R. Lindborg, A. L. Schacht, Nat. Rev. Drug Discov. 2010, 9, 203.

[5] A. Sivaraman, J. Leach, S. Townsend, T. Iida, B. Hogan, D. Stolz, R. Fry, L. Samson, S. Tannenbaum, L. Griffith, Curr. Drug Metab. 2005, 6, 569.

[6] J. Törnell, M. Snaith, Drug Discov. Today 2002, 7, 461. 
[7] S. Venkatesh, R. A. Lipper, J. Pharm. Sci. 2000, 89, 145.

[8] G. Lazzari, V. Nicolas, M. Matsusaki, M. Akashi, P. Couvreur, S. Mura, Acta Biomater. 2018, 78, 296.

[9] C. Venter, C. Niesler, Biotechniques 2018, 64, 52.

[10] E. Dohle, I. Bischoff, T. Böse, A. Marsano, A. Banfi, R. E. Unger, C. J. Kirkpatrick, Eur. Cells Mater. 2014, 27, 149.

[11] P. Miranda-Azpiazu, S. Panagiotou, G. Jose, S. Saha, Sci. Rep. 2018, 8, 8784.

[12] R. A. M. Blom, S. T. Erni, K. Krempaská, O. Schaerer, R. M. Van Dijk, M. Amacker, C. Moser, S. R. R. Hall, C. Von Garnier, F. Blank, PLoS One 2016, 11, e0163539.

[13] F. An, Y. Qu, Y. Luo, N. Fang, Y. Liu, Z. Gao, W. Zhao, B. Lin, Sci. Rep. 2016, 6, 25022.

[14] I. Maschmeyer, A. K. Lorenz, K. Schimek, T. Hasenberg, A. P. Ramme, J. Hübner, M. Lindner, C. Drewell, S. Bauer, A. Thomas, et al., Lab Chip 2015, 15, 2688.

[15] S. J. Trietsch, G. D. Israëls, J. Joore, T. Hankemeier, P. Vulto, Lab Chip 2013, 13, 3548.

[16] T. M. DesRochers, L. Holmes, L. O’Donnell, C. Mattingly, S. Shuford, M. A. O’Rourke, M. B. Rippon, W. J. Edenfield, M. R. Gevaert, D. E. Orr, et al., J. Immunother. Cancer 2015, 3, 401 .

[17] Z. Abid, S. Strindberg, M. M. Javed, C. Mazzoni, L. Vaut, L. H. Nielsen, C. Gundlach, R. S. Petersen, A. Müllertz, A. Boisen, et al., Lab Chip 2019, 19, 2905.

[18] H. D. Chirra, L. Shao, N. Ciaccio, C. B. Fox, J. M. Wade, A. Ma, T. A. Desai, $A d v$. Healthcare Mater. 2014, 3, 1648.

[19] K. J. McHugh, T. D. Nguyen, A. R. Linehan, D. Yang, A. M. Behrens, S. Rose, Z. L. Tochka, S. Y. Tzeng, J. J. Norman, A. C. Anselmo, et al., Science 2017, 357, 1138.

[20] J. R. Jørgensen, M. L. Jepsen, L. H. Nielsen, M. Dufva, H. M. Nielsen, T. Rades, A. Boisen, A. Müllertz, Eur. J. Pharm. Biopharm. 2019, 143, 98.

[21] H. J. Kim, D. Huh, G. Hamilton, D. E. Ingber, Lab Chip 2012, 12, 2165. 
[22] J. D. Wang, N. J. Douville, S. Takayama, M. Elsayed, Ann. Biomed. Eng. 2012, 40, 1862.

[23] D. Huh, H. J. Kim, J. P. Fraser, D. E. Shea, M. Khan, A. Bahinski, G. A. Hamilton, D. E. Ingber, Nat. Protoc. 2013, 8, 2135.

[24] K. Y. Chumbimuni-Torres, R. E. Coronado, A. M. Mfuh, C. Castro-Guerrero, M. F. Silva, G. R. Negrete, R. Bizios, C. D. Garcia, RSC Adv. 2011, 1, 706.

[25] M. W. Toepke, D. J. Beebe, Lab Chip 2006, 6, 1484.

[26] D. T. Butcher, T. Alliston, V. M. Weaver, Nat. Rev. Cancer 2009, 9, 108.

[27] B. Geiger, A. Bershadsky, Curr. Opin. Cell Biol. 2001, 13, 584.

[28] M. J. Paszek, N. Zahir, K. R. Johnson, J. N. Lakins, G. I. Rozenberg, A. Gefen, C. A. Reinhart-King, S. S. Margulies, M. Dembo, D. Boettiger, et al., Cancer Cell 2005, 8, 241.

[29] N. Annabi, S. M. Mithieux, P. Zorlutuna, G. Camci-unal, A. S. Weiss, A. Khademhosseini, Biomaterials 2013, 34, 5496.

[30] Y. Li, G. Huang, B. Gao, M. Li, G. M. Genin, T. J. Lu, F. Xu, NPG Asia Mater. 2016, $8, \mathrm{e} 238$

[31] R. Pimentel C., S. K. Ko, C. Caviglia, A. Wolff, J. Emnéus, S. S. Keller, M. Dufva, Acta Biomater. 2017, 65, 174.

[32] S. Hong, D. Sycks, H. F. ai Chan, S. Lin, G. P. Lopez, F. Guilak, K. W. Leong, X. Zhao, Adv. Mater. 2015, 27, 4035.

[33] R. L. DiMarco, D. R. Hunt, R. E. Dewi, S. C. Heilshorn, Biomaterials 2017, 129, 152.

[34] D. B. Gunasekara, J. Speer, Y. Wang, D. L. Nguyen, M. I. Reed, N. M. Smiddy, J. S. Parker, J. K. Fallon, P. C. Smith, C. E. Sims, et al., Anal. Chem. 2018, 90, 13331.

[35] J. Susewind, C. De Souza Carvalho-Wodarz, U. Repnik, E. M. Collnot, N. SchneiderDaum, G. W. Griffiths, C. M. Lehr, Nanotoxicology 2016, 10, 53.

[36] M. Djabourov, J. Leblond, P. Papon, J. Phys. 1988, 49, 319. 
[37] T. Heck, G. Faccio, M. Richter, L. Thöny-Meyer, Appl. Microbiol. Biotechnol. 2013, 97, 461.

[38] C. Canali, C. Mazzoni, L. B. Larsen, A. Heiskanen, Ø. G. Martinsen, A. Wolff, M. Dufva, J. Emnéus, Analyst 2015, 140, 6079.

[39] K. Kuwahara, Z. Yang, G. C. Slack, M. E. Nimni, B. Han, Tissue Eng. Part C Methods 2010, $16,609$.

[40] G. Yang, Z. Xiao, X. Ren, H. Long, H. Qian, K. Ma, Y. Guo, PeerJ 2016, 4, e2497.

[41] M. L. Jepsen, L. H. Nielsen, A. Boisen, K. Almdal, M. Dufva, Biopolymers 2019, 110, e23241.

[42] Z. Wei, S. Kale, R. El Fatimy, R. Rabinovsky, A. M. Krichevsky, Front. Neurosci. 2019, $13,1$.

[43] J. H. Sung, M. L. Shuler, Lab Chip 2009, 9, 1385.

[44] B. M. Maoz, A. Herland, E. A. Fitzgerald, T. Grevesse, C. Vidoudez, A. R. Pacheco, S. P. Sheehy, T. E. Park, S. Dauth, R. Mannix, et al., Nat. Biotechnol. 2018, 36, 865.

[45] H. Y. Tan, S. Trier, U. L. Rahbek, M. Dufva, J. P. Kutter, T. L. Andresen, PLoS One 2018, 13, e0197101.

[46] L. G. Griffith, M. A. Swartz, Nat. Rev. Mol. Cell Biol. 2006, 7, 211.

[47] M. Pinto, S. R. Leon, M. D. Appay, Biol. Cell 1983, 47, 323.

[48] G. E. Striker, J. M. Harlan, S. M. Schwartz, Methods Cell Biol. 1980, 21, 135.

[49] R. L. Nachman, E. A. Jaffe, J. Clin. Invest. 2004, 114, 1037.

[50] M. T. Donato, L. Tolosa, M. J. Gómez-Lechón, in Protoc. Vitr. Hepatocyte Res., Springer, New York, 2015, pp. 77-93.

[51] F. Leonard, E. M. Collnot, C. M. Lehr, Mol. Pharm. 2010, 7, 2103.

[52] P. Balimane, S. Chong, Drug Discov. Today 2005, 10, 335.

[53] P. Artursson, A. L. Ungell, J. E. Löfroth, Pharm. Res. 1993, 10, 1123. 
[54] I. J. Hidalgo, T. J. Raub, R. T. Borchardt, Gastroenterology 1989, 96, 736.

[55] B. Srinivasan, A. R. Kolli, M. B. Esch, H. E. Abaci, M. L. Shuler, J. J. Hickman, J. Lab. Autom. 2015, 20, 107.

[56] R. Zhang, N. B. Larsen, Lab Chip 2017, 17, 4273.

[57] H. Lee, W. Park, H. Ryu, N. L. Jeon, Biomicrofluidics 2014, 8, 054102.

[58] S. C. Ramaiahgari, M. W. Den Braver, B. Herpers, V. Terpstra, J. N. M. Commandeur, B. Van De Water, L. S. Price, Arch. Toxicol. 2014, 88, 1083.

[59] P. C. Georges, J.-J. Hui, Z. Gombos, M. E. McCormick, A. Y. Wang, M. Uemura, R. Mick, P. A. Janmey, E. E. Furth, R. G. Wells, AJP Gastrointest. Liver Physiol. 2007, 293, G1147.

[60] M. Yin, J. A. Talwalkar, K. J. Glaser, A. Manduca, R. C. Grimm, P. J. Rossman, J. L. Fidler, R. L. Ehman, Clin. Gastroenterol. Hepatol. 2007, 5, 1207.

[61] A. Asthana, W. S. Kisaalita, Drug Discov. Today 2012, 17, 810.

[62] F. Hirschhaeuser, H. Menne, C. Dittfeld, J. West, W. Mueller-Klieser, L. a. KunzSchughart, J. Biotechnol. 2010, 148, 3.

[63] E. M. Brunt, A. S. H. Gouw, S. G. Hubscher, D. G. Tiniakos, P. Bedossa, A. D. Burt, F. Callea, A. D. Clouston, H. P. Dienes, Z. D. Goodman, et al., Histopathology 2014, 64, 907.

[64] L. Perioli, G. D’Alba, C. Pagano, Eur. J. Pharm. Biopharm. 2012, 80, 621.

[65] C. Li, T. Liu, X. Cui, A. S. Uss, K. C. Cheng, J. Biomol. Screen. 2007, 12, 1084.

[66] V. Pade, S. Stavchansky, Pharm. Res. 1997, 14, 1210.

[67] C. Hilgendorf, H. Spahn-Langguth, C. G. Regårdh, E. Lipka, G. L. Amidon, P. Langguth, J. Pharm. Sci. 2000, 89, 63.

[68] L. H. Nielsen, A. Melero, S. S. Keller, J. Jacobsen, T. Garrigues, T. Rades, A. Müllertz, A. Boisen, Int. J. Pharm. 2016, 504, 98. 
[69] B. D. Rege, X. Yu Lawrence, A. S. Hussain, J. E. Polli, J. Pharm. Sci. 2001, 90, 1776.

[70] A. M. Al-Mohizea, Saudi Pharm. J. 2010, 18, 97.

[71] V. Abet, F. Filace, J. Recio, J. Alvarez-Builla, C. Burgos, Eur. J. Med. Chem. 2017, 127, 810.

[72] A. E. Thomsen, G. M. Friedrichsen, A. H. Sørensen, R. Andersen, C. U. Nielsen, B. Brodin, M. Begtrup, S. Frokjaer, B. Steffansen, J. Control. Release 2003, 86, 279.

[73] T. Imai, M. Imoto, H. Sakamoto, M. Hashimoto, Drug Metab. Dispos. 2005, 33, 1185.

[74] S. Tavelin, J. Gråsjö, J. Taipalensuu, G. Ocklind, P. Artursson, in Epithel. Cell Cult. Protoc., Humana Press, Totowa, NJ, 2002, pp. 233-272.

[75] J. Schindelin, I. Arganda-Carreras, E. Frise, V. Kaynig, M. Longair, T. Pietzsch, S. Preibisch, C. Rueden, S. Saalfeld, B. Schmid, et al., Nat. Methods 2012, 9, 676.

[76] L. H. Nielsen, S. Gordon, R. Holm, A. Selen, T. Rades, A. Müllertz, Eur. J. Pharm. Biopharm. 2013, 85, 942.

[77] G. E. Granero, G. L. Amidon, Int. J. Pharm. 2006, 317, 14. 
((Supporting Information can be included here using this template))

Copyright WILEY-VCH Verlag GmbH \& Co. KGaA, 69469 Weinheim, Germany, 2016.

Supporting Information

3D-Printed Stackable Titer Plate Inserts Supporting Three Interconnected Tissue Models for Drug transport studies.

Morten Leth Jepsen, Andreas Willumsen, Chiara Mazzoni, Anja Boisen, Line Hagner Nielsen and Martin Dufva

((write out full first and last names))

((Please insert your Supporting Information text/figures here. Please note: Supporting Display items, should be referred to as Figure S1, Equation S2, etc., in the main text...) 

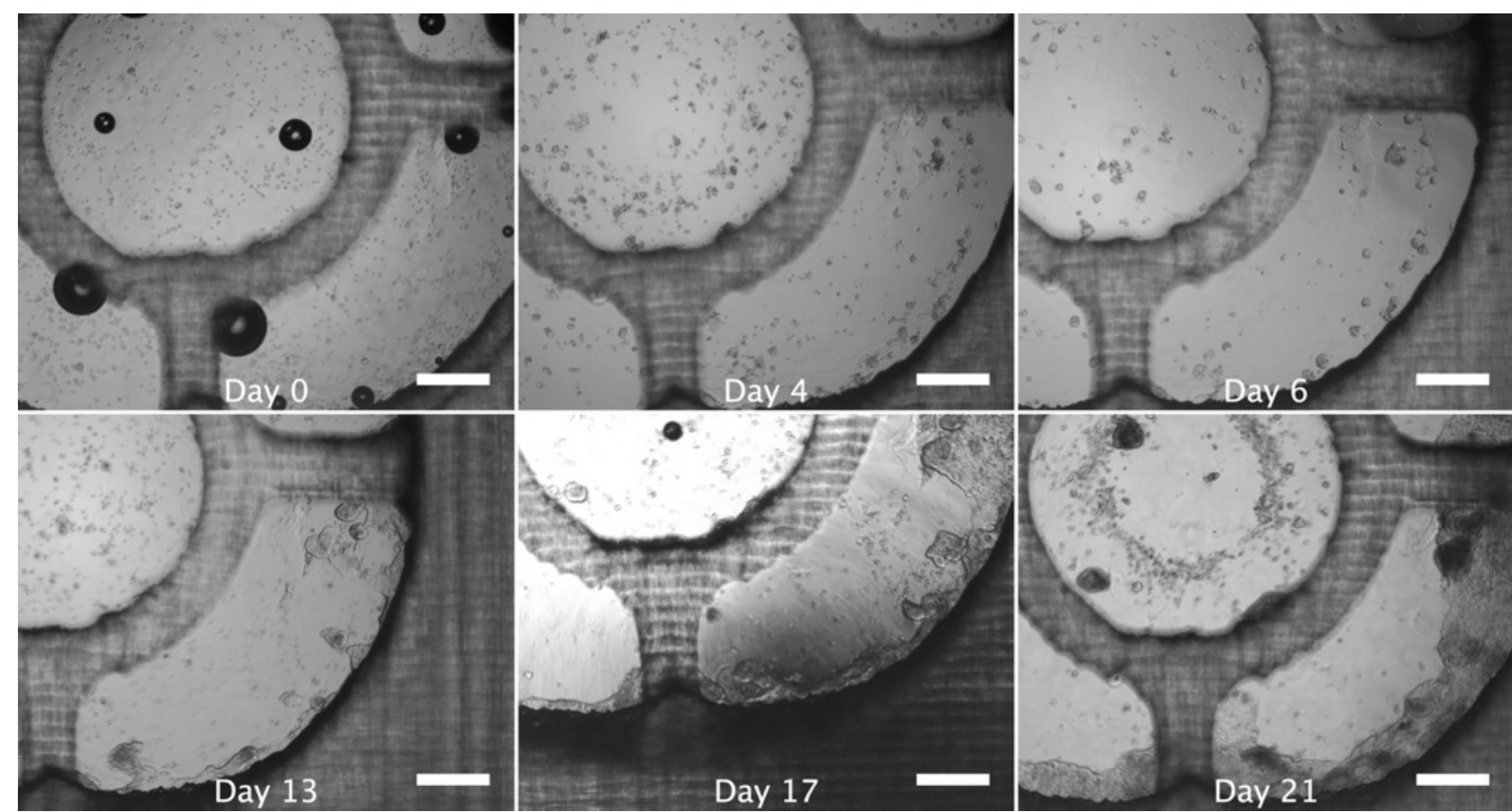

Figure S1: Growth of Caco-2 cells over 21 days on hydrogel growth-matrices when the 3Dprinted inserts are not probably cleaned. Scalebars: $1000 \mu \mathrm{m}$. 

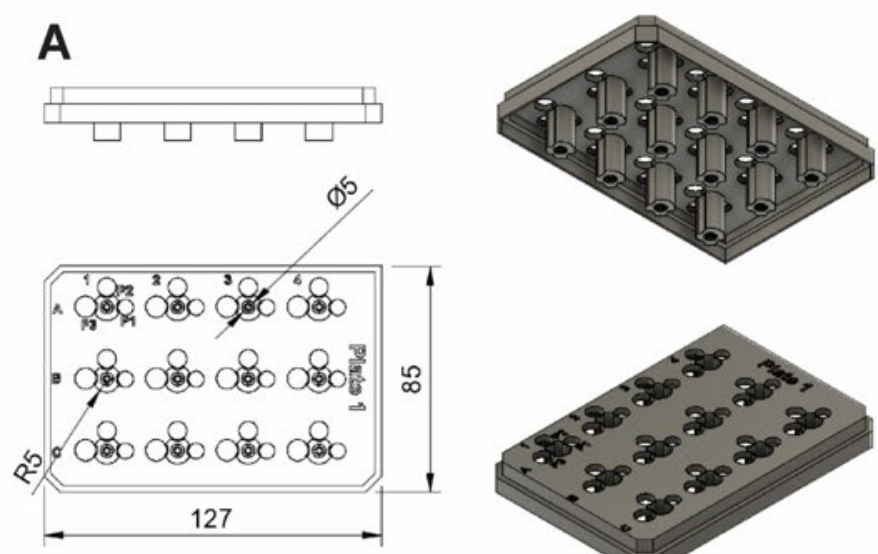

D
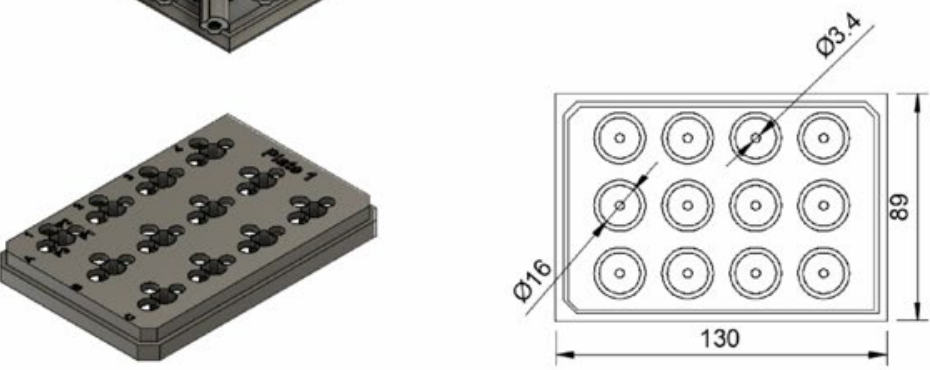

B
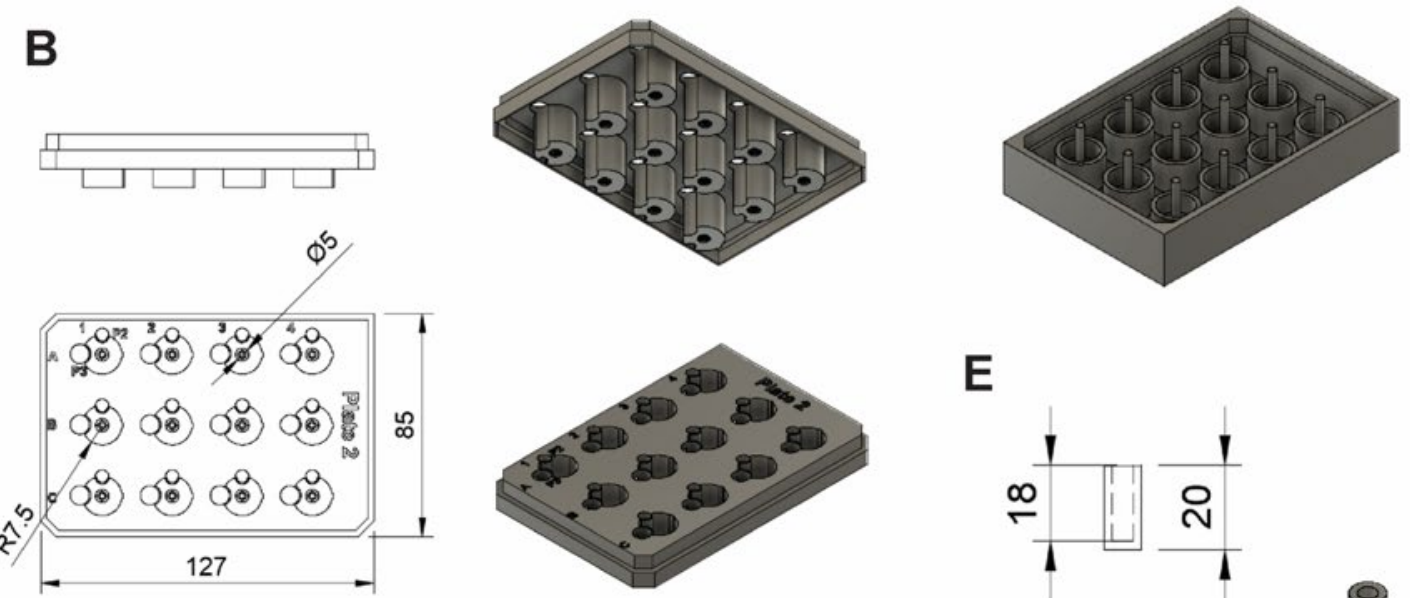

E
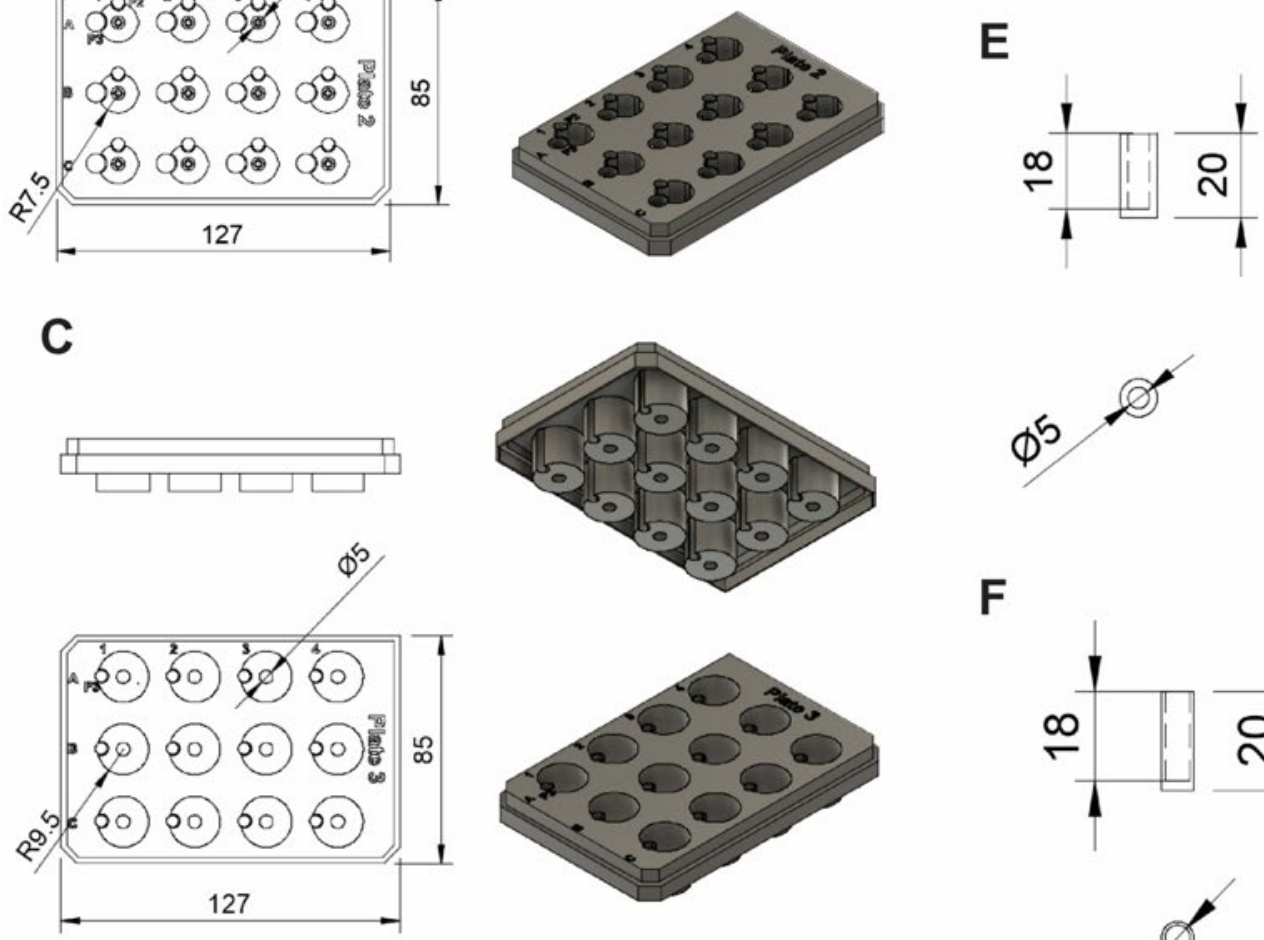

F
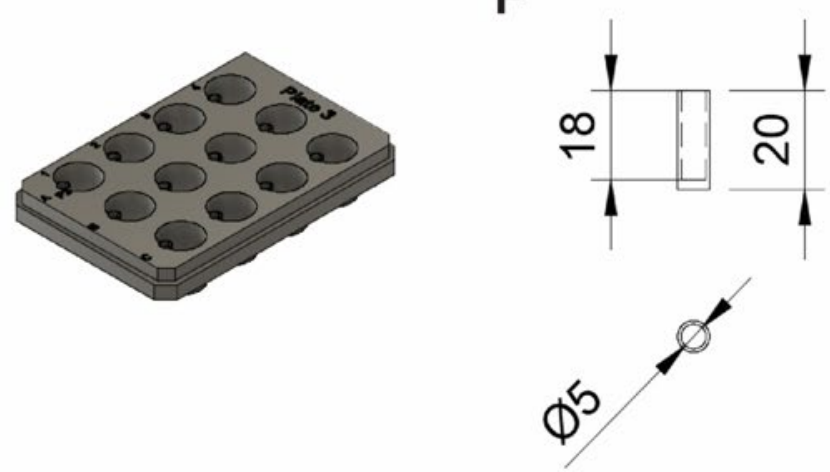

Figure S2: Technical drawing of 3D-printed inserts used for A) Caco-2, B) HUVEC, and C) HepG2 cells. D: Technical drawing of casting device. E: Technical drawing pillars used as 
plugs for 3D-printed insert for Caco-2 cells. E: Technical drawing pillars used as plugs 3Dprinted insert for HUVEC and HepG2 cells. Ø: Diameter, R: Radius. Measurements in mm. 

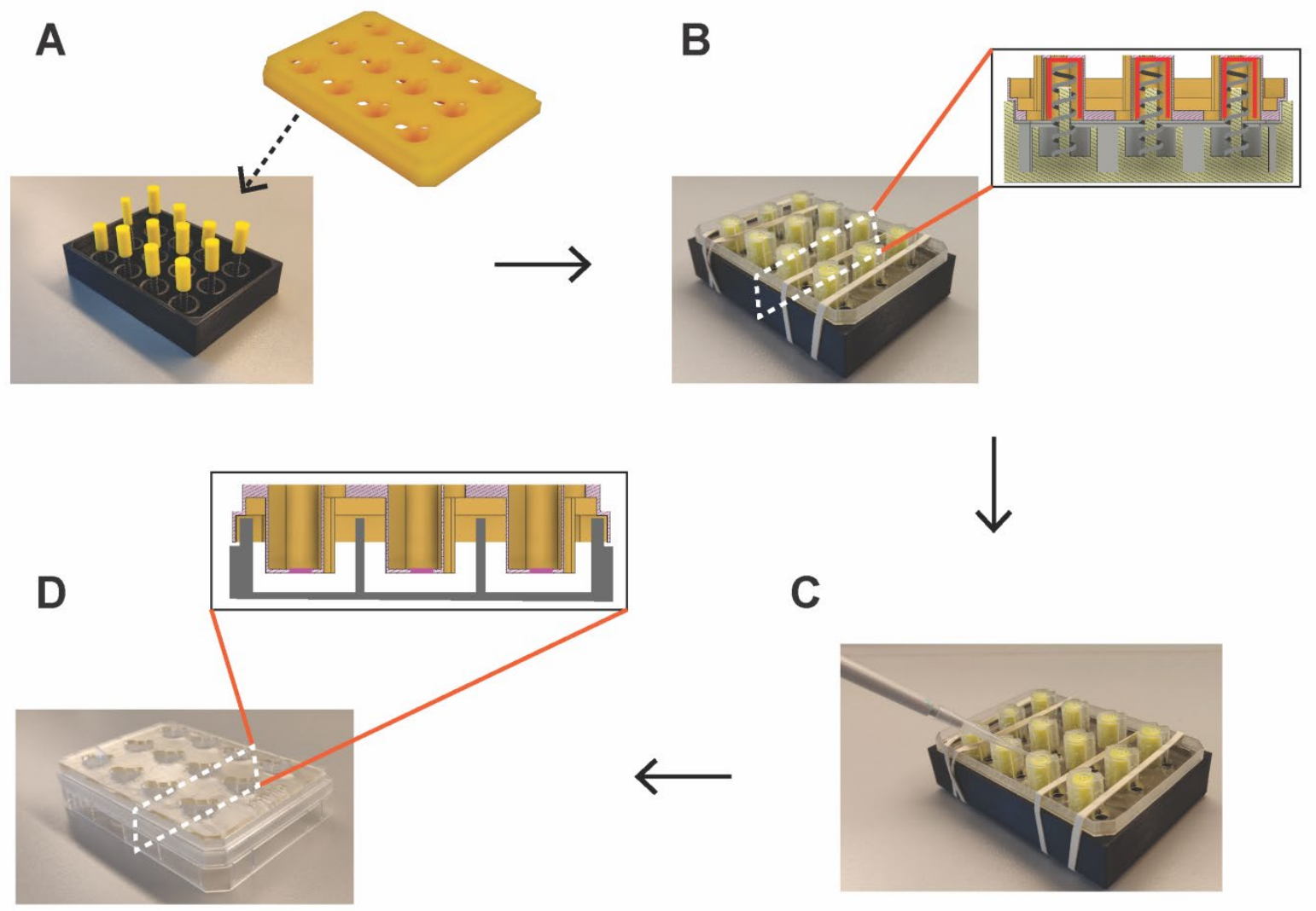

Figure S3: A: Springboard with pillars. B: Transport inserts clamped with rubber bands to the springboard. C: Casting of hydrogel in transport inserts. D: transport inserts removed from springboard and placed in a standard well plate.
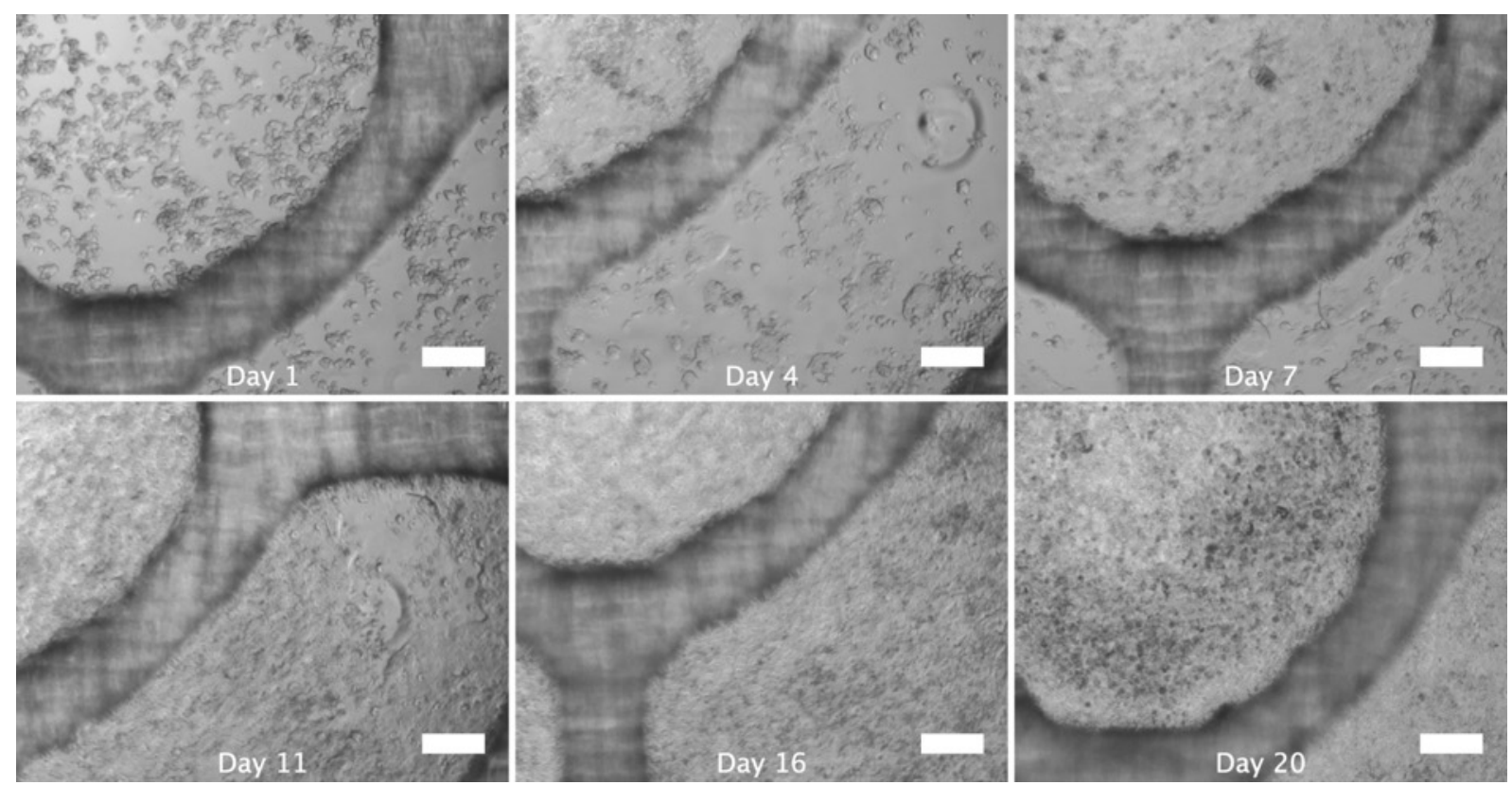
Figure S4: Growth of Caco-2 cells over 20 days on hydrogel growth-matrices. Scalebars: 500 $\mu \mathrm{m}$.

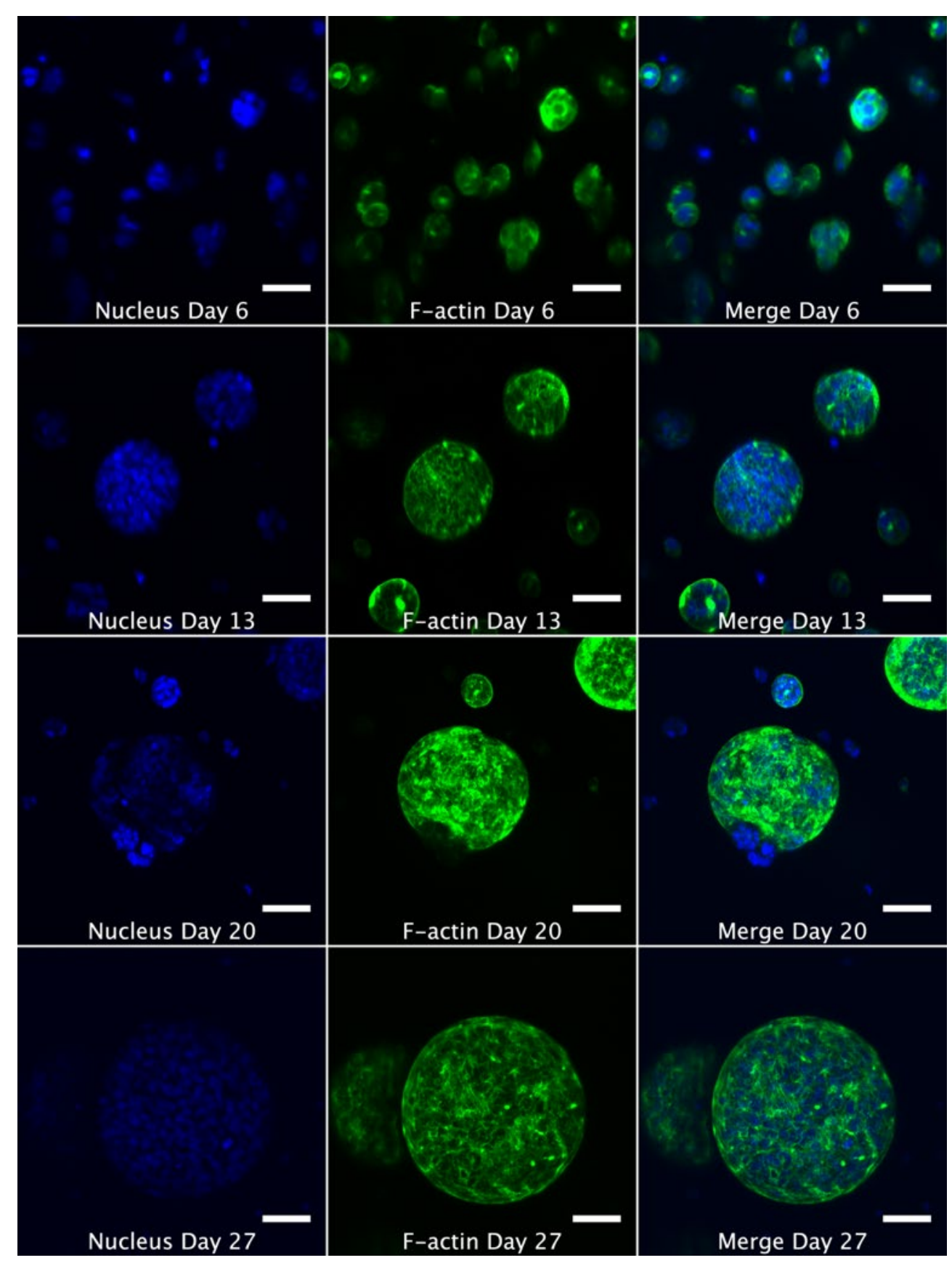

Figure S5: Images obtained by confocal microscopy representing growth of hepatic HepG2 spheroids over 6, 13, 20 and 27 days. Scalebars: $50 \mu \mathrm{m}$ 
